\title{
How warm was Greenland during the last interglacial period?
}

\author{
Amaelle Landais $^{1}$, Valérie Masson-Delmotte ${ }^{1}$, Emilie Capron ${ }^{2,3}$, Petra M. Langebroek ${ }^{4}$, Pepijn Bakker ${ }^{5}$, \\ Emma J. Stone ${ }^{6}$, Niklaus Merz ${ }^{7}$, Christoph C. Raible ${ }^{7}$, Hubertus Fischer ${ }^{7}$, Anaïs Orsi ${ }^{1}$, Frédéric Prié ${ }^{1}$, Bo Vinther ${ }^{2}$, \\ and Dorthe Dahl-Jensen ${ }^{2}$ \\ ${ }^{1}$ Laboratoire des Sciences du Climat et de l'Environnement - IPSL, UMR 8212, CEA-CNRS-UVSQ-Université Paris Saclay, \\ Gif-sur-Yvette, France \\ ${ }^{2}$ Center for Ice and Climate, Niels Bohr Institute, University of Copenhagen, Juliane Maries Vej 30, \\ 2100 Copenhagen $\varnothing$, Denmark \\ ${ }^{3}$ British Antarctic Survey, High Cross Madingley Road, Cambridge CB3 0ET, UK \\ ${ }^{4}$ Uni Research Climate, Bjerknes Centre for Climate Research, Nygårdsgaten 112-114, 5008 Bergen, Norway \\ ${ }^{5}$ College of Earth, Ocean and Atmospheric Sciences, Oregon State University, Corvallis, OR 97331, USA \\ ${ }^{6}$ BRIDGE, School of Geographical Sciences, University of Bristol, Bristol, UK \\ ${ }^{7}$ Climate and Environmental Physics, Physics Institute, and Oeschger Centre for Climate Change Research, \\ University of Bern, Sidlerstrasse 5, 3012 Bern, Switzerland
}

Correspondence to: Amaelle Landais (amaelle.landais@1sce.ipsl.fr)

Received: 29 February 2016 - Published in Clim. Past Discuss.: 18 March 2016

Revised: 18 July 2016 - Accepted: 17 September 2016 - Published: 29 September 2016

\begin{abstract}
The last interglacial period (LIG, 129-116 thousand years ago) provides the most recent case study of multimillennial polar warming above the preindustrial level and a response of the Greenland and Antarctic ice sheets to this warming, as well as a test bed for climate and ice sheet models. Past changes in Greenland ice sheet thickness and surface temperature during this period were recently derived from the North Greenland Eemian Ice Drilling (NEEM) ice core records, northwest Greenland. The NEEM paradox has emerged from an estimated large local warming above the preindustrial level $\left(7.5 \pm 1.8^{\circ} \mathrm{C}\right.$ at the deposition site $126 \mathrm{kyr}$ ago without correction for any overall ice sheet altitude changes between the LIG and the preindustrial period) based on water isotopes, together with limited local ice thinning, suggesting more resilience of the real Greenland ice sheet than shown in some ice sheet models. Here, we provide an independent assessment of the average LIG Greenland surface warming using ice core air isotopic composition $\left(\delta^{15} \mathrm{~N}\right)$ and relationships between accumulation rate and temperature. The LIG surface temperature at the upstream NEEM deposition site without ice sheet altitude correction is estimated to be warmer by $+8.5 \pm 2.5^{\circ} \mathrm{C}$ compared to the preindustrial period. This temperature estimate is consistent with the $7.5 \pm 1.8^{\circ} \mathrm{C}$ warming initially determined from
\end{abstract}

NEEM water isotopes but at the upper end of the preindustrial period to LIG temperature difference of $+5.2 \pm 2.3^{\circ} \mathrm{C}$ obtained at the NGRIP (North Greenland Ice Core Project) site by the same method. Climate simulations performed with present-day ice sheet topography lead in general to a warming smaller than reconstructed, but sensitivity tests show that larger amplitudes (up to $5^{\circ} \mathrm{C}$ ) are produced in response to prescribed changes in sea ice extent and ice sheet topography.

\section{Introduction}

It remains challenging to understand the magnitude, timing and rate of the contributions of the Greenland and/or Antarctic ice sheets to the estimated 5 to $10 \mathrm{~m}$ increase in global mean sea level during the last interglacial period (LIG, 129116 thousand years before 1950, hereafter ka) and therefore that of ice sheet vulnerability to multimillennial polar warming (Masson-Delmotte et al., 2013; Dutton et al., 2015). Therefore, constraints on past polar climate and ice sheet response are required. Additionally, polar temperature reconstructions provide a benchmark to assess the ability of climate models in capturing feedbacks which amplify the 
impact of orbital forcing on polar temperatures (MassonDelmotte et al., 2011; Otto-Bliesner et al., 2013a; Capron et al., 2014). This is also relevant for future climate projections.

Since the 1960s, numerous Greenland deep ice core records have provided evidence for layers of ice located near bedrock characterized by high values of water stable isotopes $\left(\delta^{18} \mathrm{O}_{\text {ice }}\right)$, well above preindustrial Holocene levels (Johnsen et al., 1997). The climate interpretation of the first records was limited due to poor preservation of deep samples (Camp Century, Dye 3) and the lack of remaining air content preventing any dating by synchronization with global atmospheric records (i.e., atmospheric $\delta^{18} \mathrm{O}$ of $\mathrm{O}_{2}$, hereafter $\delta^{18} \mathrm{O}_{\mathrm{atm}}$, and $\mathrm{CH}_{4}$ ) from undisturbed Antarctic records. This synchronization method was applied for the LIG interval at Summit, where ice from the LIG was unequivocally identified although not unambiguously datable, but sharp variations in $\delta^{18} \mathrm{O}_{\text {ice }}$ at GRIP (Greenland Ice Core Project) and GISP2 (Greenland Ice Sheet Project) were attributed to stratigraphic disturbances (Grootes et al., 1993; Landais et al., 2003, 2004; Suwa et al., 2006). At the NGRIP (North Greenland Ice Core Project), continuous climatic and environmental records cover the last $123 \mathrm{kyr}$ (NGRIP community members, 2004). The Greenland record was recently extended back to $128 \mathrm{ka}$ thanks to a $80 \mathrm{~m}$ segment of ice in stratigraphic order found in between disturbed layers at the bottom of the North Greenland Eemian Ice Drilling (NEEM) ice core (NEEM community members, 2013). The chronology of this core was tied to an Antarctic ice core age scale, based on common changes in atmospheric composition. The unequivocal matching between the NEEM LIG layer and the Antarctic $\delta^{18} \mathrm{O}_{\text {atm }}$ records rules out stratigraphic disturbance within this segment (NEEM community members, 2013).

Changes in NEEM air content and $\delta^{18} \mathrm{O}_{\text {ice }}$ were corrected for elevation changes due to the upstream displacement of the deposition site and combined to infer changes in ice sheet topography and changes in surface air temperature (NEEM community members, 2013). This requires assumptions regarding NEEM $\delta^{18} \mathrm{O}_{\text {ice }}$-temperature relationships. While Greenland snow isotopic composition has long been related to temperature due to Rayleigh distillation associated with cooling along air mass pathways (Dansgaard et al., 1964), it has been increasingly documented that $\delta^{18} \mathrm{O}_{\mathrm{ice}}-$ temperature relationships are neither stable in time nor in space (e.g., Jouzel et al., 1999) primarily due to changes in the precipitation intermittency but also evaporation conditions and atmospheric transport (e.g., Krinner et al., 1997; Masson-Delmotte et al., 2011).

The initial LIG temperature estimate (NEEM community members, 2013) was performed using the average Holocene $\delta^{18} \mathrm{O}_{\text {ice}}$-temperature relationship established from other central Greenland ice cores through calibration against borehole temperature at $0.5 \%{ }^{\circ} \mathrm{C}^{-1}$ (Vinther et al., 2009). This relationship was also explored in simulations using isotopically enabled atmospheric general circulation models for climate conditions warmer than the preindustrial period, either in re- sponse to increasing $\mathrm{CO}_{2}$ concentration in projections or in response to changes in orbital forcing. These models produced slopes varying from 0.3 to $0.7 \% 0^{\circ} \mathrm{C}^{-1}$ in Greenland, depending on changes in moisture sources driven by changes in sea ice and sea surface temperature patterns (MassonDelmotte et al., 2011; Sime et al., 2013). Based on these lines of evidence, a slope varying from 0.4 to $0.6 \% 0^{\circ} \mathrm{C}^{-1}$ was used to estimate the range of changes in LIG temperature based on NEEM $\delta^{18} \mathrm{O}_{\text {ice }}$ (NEEM community members, 2013). At $126 \mathrm{ka}$, and at the location of the initial snowfall deposition site (about $205 \pm 20 \mathrm{~km}$ upstream of the current NEEM site), $\delta^{18} \mathrm{O}_{\text {ice }}$ was estimated to be $3.6 \%$ above the local preindustrial level, which translated into local surface air temperature warming of $7.5 \pm 1.8^{\circ} \mathrm{C}$. After accounting for upstream effects and for Greenland ice sheet elevation change based on air content, this led to an estimate of a $8 \pm 4^{\circ} \mathrm{C}$ warming at the NEEM deposition site at $126 \mathrm{ka}$ (NEEM community members, 2013). In parallel, ice sheet simulations forced by different LIG climate scenarios were investigated to select only those compatible with a limited change in ice thickness at NEEM, based on air content data. This implied limited Greenland ice sheet deglaciation, with a contribution of 1.4 to $4.3 \mathrm{~m}$ to the LIG sea level increase (Masson-Delmotte et al., 2013).

These results led to the NEEM paradox, according to which the Greenland ice sheet appears resilient to large multimillennial surface warming. This paradox was further enhanced by the difficulty of coupled ocean-atmosphere climate models to capture such warming (Otto-Bliesner et al., 2013b; Capron et al., 2014), even during the warmest summer months (van de Berg et al., 2013), and by the inconsistency of the Greenland ice sheet retreat simulated by ice sheet models in response to such warming (e.g., Stone et al., 2013; Helsen et al., 2013). When accounting for a reduced Greenland ice sheet and a retreat in sea ice cover in the Nordic Seas, atmospheric simulations can explain up to $5^{\circ} \mathrm{C}$ annual mean warming with respect to the preindustrial period (Merz et al., 2014a, 2016). Moreover, all LIG climate modeling studies cited above strongly enhance summer precipitation seasonality in Greenland, suggesting a summer bias for LIG $\delta^{18} \mathrm{O}_{\text {ice }}$ and weaker annual mean change than the initial estimate of $8 \pm 4^{\circ} \mathrm{C}$ (Masson-Delmotte et al., 2011; Merz et al., 2014b). As an example, if we use surface temperature and precipitation rate at a monthly resolution from the Norwegian Earth System Model (NorESM) at the NEEM LIG deposition site, we observe a simulated increase in summer temperature (accumulation rate) of $3.5^{\circ} \mathrm{C}\left(7 \mathrm{~mm}\right.$ month $\left.^{-1}\right)$ and a decrease in winter temperature (accumulation rate) of $2{ }^{\circ} \mathrm{C}\left(3 \mathrm{~mm} \mathrm{month}{ }^{-1}\right)$. This seasonality effect indeed leads to a factor of 2 difference between the precipitation-weighted temperature change and the annual mean temperature change between the preindustrial period and LIG.

Recently, new information on climatic controls on NEEM $\delta^{18} \mathrm{O}_{\text {ice }}$ has emerged from present-day water isotope monitoring and multi-decadal trends from shallow ice cores 
(Steen-Larsen et al., 2011, 2014). All these datasets coherently document a surprisingly large present-day response of NEEM $\delta^{18} \mathrm{O}_{\text {ice }}$ to temperature, with a slope of $[0.8$ $1.2] \%{ }^{\circ} \mathrm{C}^{-1}$ (Masson-Delmotte et al., 2015). If relationships established from the intra-seasonal to the multi-decadal scale remain valid for earlier warm periods such as the LIG, it also implies that the initially reconstructed temperature change based on NEEM $\delta^{18} \mathrm{O}$ was overestimated.

Here, we present new, independent information on LIG annual mean temperature change for several Greenland drilling sites, using the ice core air isotopic composition $\delta^{15} \mathrm{~N}$. These Greenland records are described in Sect. 2. Section 3 details the temperature reconstructions with their associated uncertainties, with a focus on the NEEM deposition site. These temperature estimates depend on assumptions regarding the past relationship between temperature and accumulation rate. Section 4 presents a comparison to modeling outputs for discussion before the conclusions.

\section{Water and air isotope records of the last interglacial in Greenland}

\subsection{Records of water stable isotopes from multiple ice cores on a coherent chronology}

Figure 1 shows the compilation of the LIG $\delta^{18} \mathrm{O}_{\text {ice }}$ records from NGRIP, GRIP and GISP2 sites on a coherent timescale. NEEM $\delta^{18} \mathrm{O}_{\text {ice }}$ is presented on a parallel depth scale adjusted for the alignment of $\delta^{18} \mathrm{O}_{\text {atm }}$ records over the LIG section. As $\mathrm{CH}_{4}$ and $\delta^{18} \mathrm{O}_{\text {atm }}$ are globally well-mixed atmospheric tracers, comparable values are measured in the Greenland and Antarctic ice cores at the same time period, accounting for the $\mathrm{CH}_{4}$ interpolar gradient leading to slightly higher $\mathrm{CH}_{4}$ levels in Greenland than in Antarctica (e.g., Dällenbach et al., 2000). The synchronization between the records is therefore based on parallel large variations in $\mathrm{CH}_{4}$ and $\delta^{18} \mathrm{O}_{\mathrm{atm}}$ from measurements in the air trapped in bubbles. For the end of the LIG and the glacial inception, NGRIP records were placed on the AICC2012 (Antarctic ice core chronology) timescale (Bazin et al., 2013; Veres et al., 2013) using $\mathrm{CH}_{4}$ and $\delta^{18} \mathrm{O}_{\text {atm }}$ tie points between NGRIP and the Antarctic EPICA Dronning Maud Land (EDML) ice core (Capron et al., 2010). However, the AICC2012 NGRIP chronology is limited since (1) no synchronization points are available for ages older than $118 \mathrm{ka}$ (Supplement in Bazin et al., 2013; Veres et al., 2013) and (2) the mean $\mathrm{CH}_{4}$ level is significantly higher at NGRIP than in the EPICA Dome C (EDC) record (Capron et al., 2012). The latter is interpreted in part to reflect a strong increase in the interhemispheric $\mathrm{CH}_{4}$ gradient, which complicates the alignment of NGRIP and $\mathrm{EDC} \mathrm{CH}_{4}$ records (Capron et al., 2012). Additionally, a slight mismatch is observed between the LIG NGRIP and the recently published EDC $\delta^{18} \mathrm{O}_{\text {atm }}$ records (Fig. 1; Landais et al., 2013), suggesting that the AICC2012 NGRIP ice chronology may be too young by up to $2 \mathrm{kyr}$ at $121 \mathrm{ka}$.

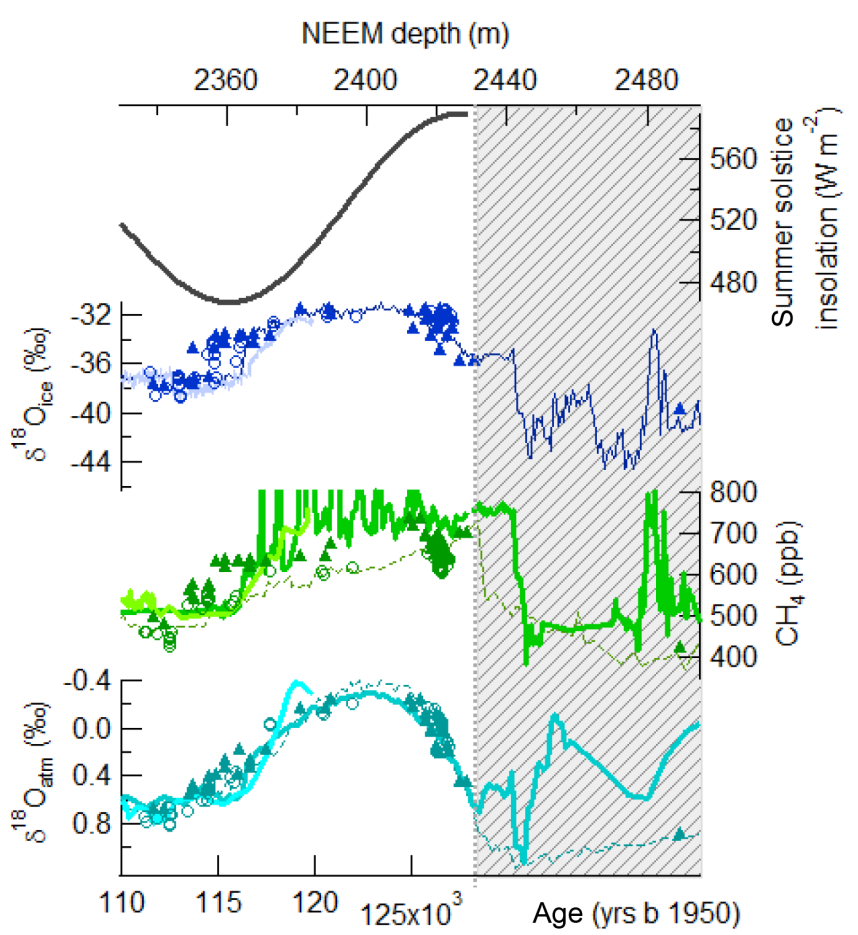

Figure 1. Synchronized Greenland $\delta^{18} \mathrm{O}_{\text {ice }}$ records. From top to bottom: summer solstice insolation at $77^{\circ} \mathrm{N}$ (black); $\delta^{18} \mathrm{O}_{\text {ice }}$ from NGRIP (light blue line), GRIP (open circles) and GISP2 (triangles) on the AICC2012 timescale (bottom axis) and NEEM $\delta^{18} \mathrm{O}_{\text {ice }}$ (dark blue line) on its depth scale (top axis); $\mathrm{CH}_{4}$ records from NGRIP (light green line), GRIP (open circles), GISP2 (triangles) and EDC (dashed line) on the AICC2012 timescale and NEEM (dark green line) on its depth axis; $\delta^{18} \mathrm{O}_{\mathrm{atm}}$ records from NGRIP (light blue), GRIP (open circles), GISP2 (triangles) and EDC (dashed line) on the AICC2012 timescale and NEEM $\delta^{18} \mathrm{O}_{\mathrm{atm}}$ (turquoise) on its depth axis. The shaded grey rectangle highlights the deepest part of the NEEM records, where no gas synchronization with Antarctic ice core records from the penultimate glaciation is feasible.

The dated GRIP and GISP2 $\delta^{18} \mathrm{O}_{\text {ice }}$ records are discontinuous because of strong stratigraphic disturbances over the bottom $300 \mathrm{~m}$ of these Summit ice cores. They were initially placed on the Vostok GT4 timescale (Petit et al., 1999) using identification of $\delta^{18} \mathrm{O}_{\mathrm{atm}} / \mathrm{CH}_{4}$ pairs and taking into account the interpolar $\mathrm{CH}_{4}$ gradient (Landais et al., 2003; Suwa et al., 2006). Here, we have transferred these $\delta^{18} \mathrm{O}_{\text {ice }}$ records on AICC2012 using the correspondence between the Vostok GT4 and AICC2012 chronologies (Fig. 1).

Finally, the LIG section of NEEM can only be dated using $\delta^{18} \mathrm{O}_{\text {atm }}$ because its $\mathrm{CH}_{4}$ record is contaminated by in situ production, relating to local summer melt during the LIG (NEEM community members, 2013). Figure 1 displays the NEEM $\delta^{18} \mathrm{O}_{\text {ice }}$ record on its depth scale between 2350 and $2490 \mathrm{~m}$, where the linear alignment of depth with AICC2012 is based on the resemblance between EDC and NEEM $\delta^{18} \mathrm{O}_{\text {atm }}$ records. 
The continuous NEEM section spanning the LIG ends just after $128 \mathrm{ka}$ (on the AICC2012 timescale). Indeed, the characteristic abrupt increase in $\mathrm{CH}_{4}$ and high $\delta^{18} \mathrm{O}_{\text {atm }}$ level identified in Antarctic records at $128 \mathrm{ka}$ is absent from the NEEM record. This reveals that the NEEM ice core does not encompass any ice from the penultimate deglaciation at that point, similar to GISP2, GRIP or NGRIP (Fig. 1). Whether this hiatus arises from the disappearance of this layer due to melt under warm early LIG conditions or due to specific thinning and flow associated with different physical properties of glacial versus transition ice remains to be fully assessed.

\subsection{NEEM air $\delta^{15} \mathrm{~N}$ record}

Relative to the free-atmosphere mean value, the $\delta^{15} \mathrm{~N}$ value in air trapped in ice cores is influenced by gravitational fractionation directly related to temperature and to the depth at which bubble lock-in occurs. Changes in firn lock-in depth (LID) can be related to changes in surface accumulation and temperature: an increase in temperature leads to a decrease in the LID because of faster metamorphism, while higher accumulation rates lead to an increase in the LID. The development of firn densification models allows the simulation of the LID evolution as a function of surface climatic conditions (e.g., Herron and Langway, 1980; Goujon et al., 2003; Li and Zwally, 2004; Helsen et al., 2008; Arthern et al., 2010; Ligtenberg et al., 2015). While there is still a model-data mismatch at cold sites of central Antarctica (Capron et al., 2013), the comparison between firn models and $\delta^{15} \mathrm{~N}$ data can be used for testing quantitative temperature and accumulation rate reconstructions in Greenland and high-accumulation sites in Antarctica (Guillevic et al., 2013; Kindler et al., 2014; Buizert et al., 2015). During rapid surface temperature changes in Greenland (e.g., DansgaardOeschger events), $\delta^{15} \mathrm{~N}$ is also influenced by thermal fractionation (Severinghaus et al., 1998). However, no rapid $\delta^{18} \mathrm{O}_{\text {ice }}$ changes are found during the LIG, and overall stable NEEM $\delta^{15} \mathrm{~N}$ values are also coherent with gravitational fractionation occurring at a stable surface accumulation rate and temperature (Fig. 2).

The single exception is a negative spike recorded at $2384 \mathrm{~m}$ depth, which coincides with the strongest $\mathrm{CH}_{4}$ spike, as well as a negative excursion of the ${ }^{10} \mathrm{Be}$ record (SturevikStorm et al., 2014). We suggest that this singular event reflects positive surface temperatures, leading to intense surface melt and large in situ $\mathrm{CH}_{4}$ production (Orsi et al., 2015). Firn air transport and thus $\delta^{15} \mathrm{~N}$ are not expected to be significantly affected by melt layers at the surface (Keegan et al., 2014). This probably explains why most of the $\mathrm{CH}_{4}$ spikes are not associated with any changes in the $\delta^{15} \mathrm{~N}$ signal. Still, for the negative $0.07 \% \circ \delta^{15} \mathrm{~N}$ excursion at $2384 \mathrm{~m}$ (corresponding to $\sim 121 \mathrm{ka}$ on the NEEM LIG age scale), we propose that positive surface temperatures led to a sudden shrinking of the firn by about $15 \mathrm{~m}$ using the expression

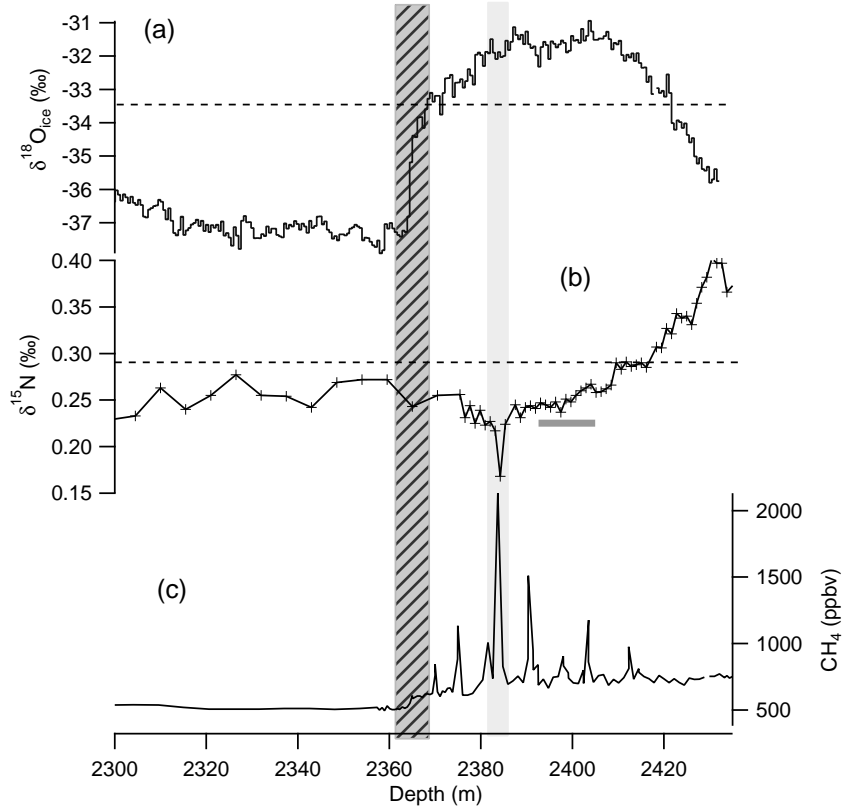

Figure 2. NEEM $\delta^{18} \mathrm{O}_{\text {ice }}$ (top), $\delta^{15} \mathrm{~N}$ (middle) and $\mathrm{CH}_{4}$ (bottom) spanning the LIG. The hatched rectangle indicates the stratigraphic disturbance identified in the upper part of the LIG section. The light grey rectangle highlights the single negative peak in $\delta^{15} \mathrm{~N}$ at NEEM during the LIG, corresponding to the strongest positive peak in $\mathrm{CH}_{4}$, both peaks being identified at $2384 \mathrm{~m}$ depth. The grey and bold horizontal segment indicates the depth range over which the $\delta^{15} \mathrm{~N}$ average has been done.

of $\delta^{15} \mathrm{~N}$ gravitational settling in the firn column:

$\delta^{15} \mathrm{~N}=\exp \left(\frac{g \times \text { LID }}{R \times T_{\text {mean }}}\right)-1 \cong \frac{g \times \text { LID }}{R \times T_{\text {mean }}}$,

where $g$ is acceleration due to gravity, $R$ the ideal gas constant and $T_{\text {mean }}(\mathrm{K})$ the mean temperature of the firn when bubbles are isolated.

For the rest of the LIG our $\delta^{15} \mathrm{~N}$ record shows only very subtle changes, and we take the mean $\delta^{15} \mathrm{~N}$ value of $0.251 \%$ o over the time interval $122-126 \mathrm{ka}$ to obtain a representative mean $\delta^{15} \mathrm{~N}$ value (Table 1).

\subsection{Spatial structure of isotopic anomalies}

To assess the spatial extent of the isotopic anomalies, the magnitudes of $\delta^{15} \mathrm{~N}$ are compared to the water stable isotope $\left(\delta^{18} \mathrm{O}_{\text {ice }}\right.$ and deuterium excess, hereafter $d$-excess) anomalies recorded in different Greenland ice cores between the LIG and the preindustrial period (Table 1).

For $\delta^{18} \mathrm{O}_{\text {ice }}$, the strongest increase from the preindustrial period to the LIG is recorded at Summit $(+3.4 \%$ ) and NGRIP $(+3.3 \% o)$ and the smallest increase at NEEM $(+2.1 \% o)$. However, the NEEM anomaly must be corrected for upstream effects: due to ice flow, the LIG ice at NEEM originates from a $330 \mathrm{~m}$ higher upstream location (at the 
Table 1. Characteristics of Greenland deep ice core in the preindustrial period and during the LIG. The uncertainty corresponds to the standard error of the mean. Where data was compiled from previous studies, the references for the number in this table are taken from 1. Buizert et al. (2012); 2. Guillevic et al. (2013); 3. Kobashi et al. (2008), Bender et al. (2006); 4. Masson-Delmotte et al. (2005); 5. Capron et al. (2012); 6. Jouzel et al. (2007); 7. NEEM community members (2013); 8. Masson-Delmotte et al. (2015).

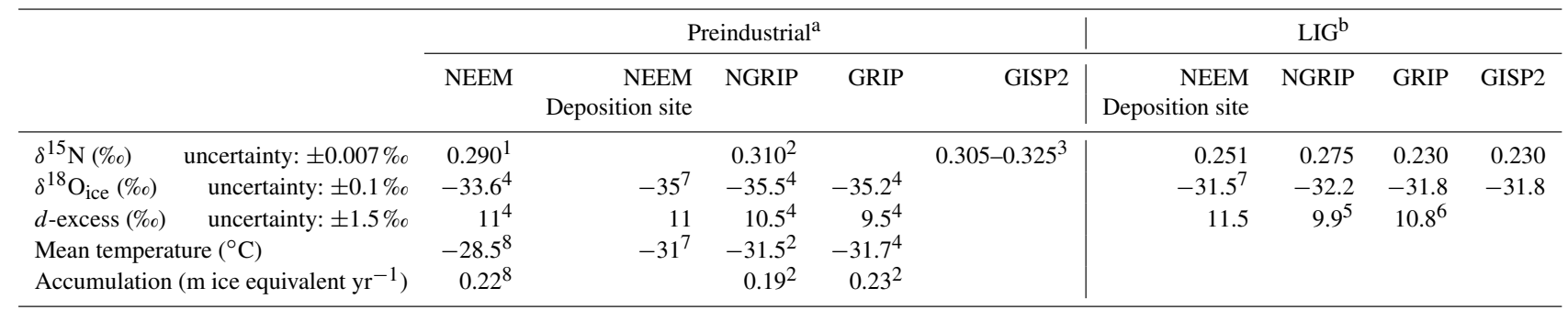

a The accumulation rate, $\delta^{18} \mathrm{O}$ and $d$-excess values attributed to the preindustrial conditions correspond to averages over the last 200 years. For $\delta^{15} \mathrm{~N}$, it corresponds to the value at the bottom of the firn (itself built up over the last 200 years). The mean temperature is derived from borehole measurements. ${ }^{\text {b }}$ For determining the $\delta^{18} \mathrm{O}_{\text {ice }}, \delta^{15} \mathrm{~N}$ and $d$-excess values attributed to the LIG, we have taken the average of the corresponding records for NEEM, GRIP and GISP2 between 122 and $126 \mathrm{ka}$ (excluding negative $\delta^{15} \mathrm{~N}$ peak at $2384 \mathrm{~m}$ at NEEM). At NGRIP, we have probably missed the first part of the LIG and probably the optimum of the LIG. The values indicated here correspond to the average over the 1000 oldest years recorded in the NGRIP ice core (119 to 120 ka on the AICC2012 timescale).

southeast of NEEM) where mean annual $\delta^{18} \mathrm{O}$ today is approximately $-35 \%$ (NEEM comm members, 2013). At this deposition site, the LIG isotopic anomaly is therefore $3.6 \%$, close to the value at Summit. We conclude that changes in $\delta^{18} \mathrm{O}_{\text {ice }}$ are rather homogeneously $\sim 3.2-3.6 \%$ higher in the LIG than in the preindustrial period in central and northwest Greenland (Table 1).

$D$-excess is not significantly different between the LIG and the preindustrial period at the different drilling sites listed in Table 1. Preindustrial $d$-excess values are also very similar among these different sites. This is the reason why extrapolating the surface $d$-excess values in the NEEM-NGRIP regions enables us to estimate the preindustrial $d$-excess at the upstream NEEM deposition site to a conservative value of $11 \%$.

Assuming that no abrupt climate change took place from 122 to $126 \mathrm{ka}$ (a hypothesis supported by the relatively flat NEEM $\delta^{18} \mathrm{O}_{\text {ice }}$ record), changes in mean $\delta^{15} \mathrm{~N}$ are expected to reflect changes in LID. The spatial structure of the $\delta^{15} \mathrm{~N}$ changes differs from the pattern of $\delta^{18} \mathrm{O}_{\text {ice. }}$. Indeed, the smallest $\delta^{15} \mathrm{~N}$ increase is observed at NGRIP $(-0.02 \%$ ) (but the record ends at $120 \mathrm{ka}$ ) and the largest one at GRIP and GISP2 $(-0.07$ to $-0.09 \%$ o), with an intermediate signal at NEEM $(-0.04 \%$ ) , albeit with an inherent uncertainty due to the lack of data for the NEEM deposition site today. Because of stratigraphic disruptions, no continuous record is available at Summit. We thus cannot exclude that low $\delta^{15} \mathrm{~N}$ levels observed at GRIP and GISP2 on 122-126 ka ice sections reflect a temporary $\delta^{15} \mathrm{~N}$ decrease caused by thermal fractionation or firn shrinking as for the NEEM $\delta^{15} \mathrm{~N}$ value at $2384 \mathrm{~m}$ (121 ka). We therefore note regional differences for the different available datasets but stress their heterogeneities (time span, discontinuity, and lack of present-day reference) preventing any robust conclusion.

\section{Temperature reconstructions}

\subsection{Reconstructions based on $\delta^{18} \mathrm{O}_{\text {ice }}$}

Today, NW Greenland accumulation is biased towards summer precipitation (based on regional and general circulation atmospheric models; Steen-Larsen et al., 2011). NEEM summer $\delta^{18} \mathrm{O}_{\text {ice }}$ was monitored through continuous measurements of surface water vapor isotopic composition in 2010 2012 (Steen-Larsen et al., 2013, 2014), revealing a $\delta^{18} \mathrm{O}_{\text {ice }}-$ temperature slope of $0.85 \%{ }^{\circ} \mathrm{C}^{-1}$ on the intra-summer scale. From 1979 to 2007, the increasing trend of $\delta^{18} \mathrm{O}_{\text {ice }}$ recorded in NEEM shallow ice cores was scaled to simulated and estimated local surface air temperature trends, resulting in a multi-decadal slope of $1.05 \pm 0.2 \% 0^{\circ} \mathrm{C}^{-1}$ for warming above preindustrial conditions (Masson-Delmotte, 2015). These various estimates suggested that the average Holocene $\delta^{18} \mathrm{O}$-temperature relationship of $0.5 \% 0^{\circ} \mathrm{C}^{-1}$ based on the calibration with borehole temperature data at other Greenland ice core sites (Vinther et al., 2009, 2010) may not be valid for NEEM. Differences between Greenland locations are expected due to changes in the seasonality of precipitation (summer bias at NEEM but not in central or south Greenland) and moisture origin as well as possible changes in boundary layer stability and relationships between the surface and temperature.

Applying the multi-decadal temporal slope given above, the LIG $\delta^{18} \mathrm{O}_{\text {ice }}$ anomaly at the NEEM deposition site translates into a warming of $2.9-4.2^{\circ} \mathrm{C}$, twice smaller than the initial estimate based on Holocene calibrations for other sites. Still, it is difficult to assess whether the present-day calibration can apply to the LIG, marked by a different orbital forcing than today, likely with a reduced sea ice extent and different moisture transport pathways (Sime et al., 2013). The second-order isotopic parameter, the $d$-excess, can provide information on evaporation conditions. Present-day monitoring studies depict low $d$-excess values for subtropical moisture, contrasting with high $d$-excess values for moisture from 
sea ice margin areas (e.g., Steen-Larsen et al., 2015; Pfahl et al., 2014). The $d$-excess is also affected by distillation and will decrease in polar regions if $\delta^{18} \mathrm{O}_{\text {ice }}$ increases without any moisture source change. As noted above, available LIG $d$-excess data (Table 1) are slightly (insignificantly) above preindustrial levels. A stable or higher $d$-excess level together with an $\delta^{18} \mathrm{O}_{\text {ice }}$ increase is therefore understood to reflect a slight poleward shift of moisture sources. In turn, this would imply reduced distillation for $\delta^{18} \mathrm{O}_{\text {ice }}$ and a reduced slope of the relationship between $\delta^{18} \mathrm{O}_{\text {ice }}$ and temperature (Sime et al., 2013) more in line with the average Holocene calibration.

\subsection{Reconstructions based on air $\delta^{15} \mathrm{~N}$}

In the absence of abrupt surface temperature changes, $\delta^{15} \mathrm{~N}$ is only affected by the gravitational signal linked to firn LID; the latter is directly related to changes in temperature and accumulation rate. Thus, if accumulation is known, past temperature changes can be inferred from $\delta^{15} \mathrm{~N}$. As neither accumulation nor temperature is independently known for the LIG, we have to constrain the accumulation-temperature relationship in the past based on observation and/or models. We now describe the different steps of our procedure to estimate the temperature of the NEEM deposition site during the LIG from $\delta^{15} \mathrm{~N}$ measurements.

\subsubsection{Different estimates of the link between temperature and accumulation rate in Greenland}

i. Accumulation rate and temperature can be linked through thermodynamic laws and ice sheet topography, despite significant uncertainties associated with atmospheric transport characteristics that lead to regional variability (Kapsner et al., 1995; Merz et al., 2014b). In a first approximation, temperature and moisture content of an air mass are linked through saturation pressure (“ $P_{\text {sat }}$ approach"). This first-order relationship between accumulation rate and temperature has long been used for Antarctic ice core chronologies (Lorius et al., 1985; Ritz, 1992), with

$$
A(t)=A\left(t_{0}\right) \times \frac{\left[\left(\partial P_{\mathrm{sat}} /(T+273)\right) / \partial T\right]_{t}}{\left[\left(\partial P_{\mathrm{sat}} /(T+273)\right) / \partial T\right]_{t 0}},
$$

where $A(t)$ and $A\left(t_{0}\right)$ are the accumulation rates at time $t$ and $t_{0}$, respectively, $P_{\text {sat }}$ the saturation pressure over ice, and $T$ the temperature in ${ }^{\circ} \mathrm{C}$.

ii. Empirical relationships between accumulation rate and Greenland temperature have been provided by different methods. The dataset obtained in $1952-1955$ by Benson (1962) remains a reference today for evaluating surface accumulation rate reconstructions above the Greenland ice sheet (e.g., Hawley et al., 2014; Munk et al., 2003). Surface accumulation rate and temperature data from 146 sites show an exponential increase in accumulation rate versus temperature. Within the associated $1 \sigma$ envelope, the increase encompasses the accumulation rate versus temperature increase deduced from the $P_{\text {sat }}$ approach. This spatial relationship between accumulation rate and temperature is however associated with a very large uncertainty envelope challenging the validity of any relationship between temperature and accumulation in Greenland.

iii. Based on the GISP2 ice core records over the last deglaciation, Kapsner et al. (1995) showed that the relationship between Greenland accumulation rate and temperature was not stable because of variations in atmospheric circulation. Still, they were able to propose a temporal relationship between accumulation rate based on annual layer counting and $\delta^{18} \mathrm{O}-$ or temperature reconstructed from $\delta^{18} \mathrm{O}$ - and a calibration based on borehole temperature measurements (leading to a $\delta^{18} \mathrm{O}$ vs. temperature slope of $0.53 \% 0^{\circ} \mathrm{C}^{-1}$ ). The inferred sensitivity of snow accumulation rate to temperature change during the interglacial period varies from $0.9 \%{ }^{\circ} \mathrm{C}^{-1}$ (Holocene) to $7.5 \%{ }^{\circ} \mathrm{C}^{-1}$ (BøllingAllerød), with an uncertainty encompassing zero.

More recently, Buchardt et al. (2012) followed a similar approach but using numerous ice cores. They used an array of 52 shallow ice cores spanning the last decades to centuries with accumulation rate estimates from annual layer counting on $\delta^{18} \mathrm{O}_{\text {ice }}$ profiles. They identified different temperature vs. accumulation rate relationships from one region to another. In central and north Greenland corresponding to the location of the NEEM, NGRIP, GRIP and GISP2 deep ice cores, the Buchardt approach suggests a sensitivity of 1.5 to $9.4 \%{ }^{\circ} \mathrm{C}^{-1}$ with an uncertainty encompassing zero. This sensitivity is obtained with a $\delta^{18} \mathrm{O}$ vs. temperature sensitivity slope of $0.67 \%{ }^{\circ} \mathrm{C}^{-1}$ so that the Kapsner and Buchardt estimates agree on a 0 to $14 \% \% o^{-1}$ accumulation rate vs. $\delta^{18} \mathrm{O}$ sensitivity.

iv. Masson-Delmotte et al. (2015) used estimates of snow accumulation rate and ice $\delta^{18} \mathrm{O}$ in four shallow cores in the NEEM area together with accumulation rate, temperature and when possible snowfall $\delta^{18} \mathrm{O}$ reconstructions from different model simulations (ECHAM5, Global Climate Model developed by the Max Planck Institute for Meteorology; LMDZ, Global Climate Model developed by the Laboratoire de Météorologie Dynamique; MAR, Modèle Atmosphérique Régional) nudged to available climate reanalyses over the 19792007 period. In addition to model outputs or temperature gridded reconstruction (Box et al., 2009), the amplitude of temperature increase at NEEM can also be estimated using borehole temperature measurements. Gathering the different sources of information for the 
strong warming period of 1979-2007 leads to a relatively high slope between accumulation rate and temperature $\left(10\right.$ to $15.9 \%{ }^{\circ} \mathrm{C}^{-1}$, the highest value being obtained using outputs from the MAR model nudged to ERA-40 and ERA-Interim reanalyses; Uppala et al., 2005; Dee et al., 2011). In this study, the sensitivity of accumulation rate vs. $\delta^{18} \mathrm{O}$ can be estimated through the regression between the NEEM $\delta^{18} \mathrm{O}$ and accumulation rate increases over the period 1979-2007, leading to a value of $10 \% \% o^{-1}$, in agreement with the Buchardt estimate. Another solution is to use the $\delta^{18} \mathrm{O}$ vs. temperature estimate based on NEEM $\delta^{18} \mathrm{O}$ measurements vs. borehole temperature over the recent warming trend $\left(0.8 \% 0^{\circ} \mathrm{C}^{-1}\right)$ together with the accumulation rate vs. temperature estimate given above, hence leading to a maximum accumulation rate vs. $\delta^{18} \mathrm{O}$ sensitivity of $13 \% \% o^{-1}$, again within the range of the Buchardt estimate .

v. Alternative estimates of accumulation rate at the NEEM deposition site are also provided by ${ }^{10} \mathrm{Be}$ data. SturevikStorm et al. (2014) compiled the mean Holocene ${ }^{10} \mathrm{Be}$ concentration over eight Greenland sites and determined the spatial relationship against mean accumulation rate estimates. This relationship was then applied to LIG ${ }^{10} \mathrm{Be}$ data from NEEM, leading to the conclusion that the accumulation rate was $65-90 \%$ higher than today at the NEEM deposition site ("10 Be approach"). However, the present-day spatial gradients in ${ }^{10} \mathrm{Be}$ concentration are caused by spatially varying contributions of wet deposition to the overall ${ }^{10} \mathrm{Be}$ deposition, assuming a homogeneous atmospheric ${ }^{10} \mathrm{Be}$ aerosol deposition over Greenland. This latter assumption implies that the atmosphere above Greenland is well mixed with respect to ${ }^{10} \mathrm{Be}$ after transport from the location of troposphere-stratosphere foldings. These are the main entrance pathways of stratospheric aerosols into the extratropical Northern Hemisphere troposphere. The LIG climate is characterized not only by likely enhanced precipitation above Greenland (accumulation) but also higher wet deposition during aerosol transport to Greenland due to higher precipitation rates. As a result, higher scavenging of ${ }^{10} \mathrm{Be}$-bearing aerosol en route must have led also to a lower atmospheric ${ }^{10} \mathrm{Be}$ concentration over Greenland than today. The LIG accumulation estimate by Sturevik-Storm et al. (2014) is therefore most likely an overestimation and the assumption of Sturevik-Storm et al. (2014) that ${ }^{10} \mathrm{Be}$ concentration is only controlled by the accumulation rate at the NEEM site may be challenged. More generally, the use of other chemical aerosol species as accumulation rate tracers is hampered by potential changes in the LIG atmospheric concentrations due to emission changes. Qualitatively, a correction of deposition effects using the Buchardt et al. (2012) approach, representative of northwest Green- land, leads to LIG atmospheric concentrations of all chemical aerosol tracers similar to today. In contrast much higher LIG accumulation rates as estimated by Sturevik-Storm et al. (2014) or no changes in accumulation between the LIG and the Holocene imply an unrealistic change in atmospheric aerosol concentrations for several aerosol tracers. Indeed, if we compare aerosol species that are dominated by wet deposition such as $\mathrm{Na}^{+}$(sea salt aerosol) and $\mathrm{NO}_{3}^{-}$(lightning activity, biological activity), we see that the concentration in the ice in the LIG is lower than in the Holocene (about $50 \%$ ). As these species are mainly wet deposited, this is only possible if the atmospheric aerosol concentration was also reduced by $50 \%$ at that time. It is unlikely that both $\mathrm{Na}^{+}$and $\mathrm{NO}_{3}^{-}$(which have completely different sources and transport pathways) have a $50 \%$ reduction of source emissions. Another solution to explain the reduction of $50 \%$ in atmospheric $\mathrm{Na}^{+}$and $\mathrm{NO}_{3}^{-}$concentration over the ice is to imply an increase in the precipitation rate along the transport pathway and thus an increase in wet deposition en route. The chemistry suggests that the precipitation rate during transport in the Northern Hemisphere was significantly higher during the LIG than during the Holocene and there is no reason why Greenland would not be affected by this general increased accumulation rate. Based on the changes in various chemical tracers in the ice (sea salt aerosol, biogenic aerosol, mineral dust), we thus conclude that the LIG accumulation was likely $20 \%$ higher than in the preindustrial period and similar to the Buchardt approach for northwest Greenland.

vi. Atmospheric general circulation model outputs do not suggest important changes in accumulation rate for the LIG compared to preindustrial values, in line with the small simulated change in annual mean surface temperature (Sect. 3.3). A comparison of some of the model outputs (presented in Lunt et al., 2013) shows very limited accumulation increase (less than $5 \%$ ) over central Greenland. Stronger increases in accumulation rate in the LIG associated with significantly warmer than preindustrial temperature were obtained in relation to a reduction of sea ice in the Nordic Seas $(10 \%$ increase in accumulation; Merz et al., 2016). Finally, it has been shown that the geometry of the Greenland ice sheet and topographic changes can lead to various local accumulation scenarios for the LIG at the upstream NEEM deposition site (Merz et al., 2014b): depending on the prescribed LIG ice sheet topography, the modeled accumulation rate at LIG can be $25 \%$ lower to $13 \%$ higher than the preindustrial accumulation rate. The lowest estimate is linked to a change in the trajectory of air mass to the NEEM deposition site, with an increased eastward origin. The validity of such a scenario could be assessed by comparing simulated and measured $d$-excess variations. 
The data presently available show similar $d$-excess levels in the LIG and preindustrial periods and therefore do not support a significant change in moisture source and trajectory (Table 1). Often associated with relatively small temperature changes, these modeled accumulation rate scenarios for the LIG are at the lower end of the accumulation rate scenarios discussed above and encompass the possibility of a scenario with no change in the accumulation rate.

\subsubsection{Measured vs. modeled evolution of $\delta^{15} \mathrm{~N}$ with respect to temperature and accumulation rate changes}

Our $\delta^{15} \mathrm{~N}$ data are compared with those simulated using a firn densification model forced by these different accumulation rate versus temperature relationships for the LIG. The firnification model relates LID to accumulation rate and temperature. Here, we use the Goujon et al. (2003) model in steady state to calculate LID and the barometric Eq. (1) to translate LID changes into $\delta^{15} \mathrm{~N}$ changes.

The model correctly captures the present-day $\delta^{15} \mathrm{~N}$ values for NEEM and NGRIP, using the current mean values for accumulation rate and temperature (Fig. 3). At NEEM and NGRIP, firn studies have recently provided an accurate determination of the LID and $\delta^{15} \mathrm{~N}$ profiles (Guillevic et al., 2013; Buizert et al., 2013). At GISP2, there exists no proper determination of the LID due to discontinuous sampling of air bottles and a large scatter of $\delta^{15} \mathrm{~N}$ values measured at the bottom of the firn, ranging between 0.305 and $0.325 \%$ (Bender et al., 2006). An average value of $0.31 \%$ is obtained from high-resolution $\delta^{15} \mathrm{~N}$ measurements over the last 4000 years on the GISP 2 core (Kobashi et al., 2008). For the present day, our simulation at GISP2 $\left(\delta^{15} \mathrm{~N}\right.$ of $0.325 \%$ o therefore lies at the upper limit of available measurements (Table 1).

\subsubsection{Reconstructing Greenland LIG temperature}

In order to estimate the LIG firn temperature (at the deposition sites), Fig. 3 displays the $\delta^{15} \mathrm{~N}$ data points for each ice core site on contours of the simulated $\delta^{15} \mathrm{~N}$ values as a function of temperature and accumulation. In addition, we display the different accumulation rate estimates detailed in Sect. 3.2.1. We use the different relationships for accumulation rate vs. $\delta^{18} \mathrm{O}$ sensitivity together with the $2.1 \%$ increase between the present-day $\delta^{18} \mathrm{O}$ at NEEM and the LIG $\delta^{18} \mathrm{O}$ at the NEEM deposition site to infer a range of accumulation rates for the NEEM LIG, compatible with the approaches of Buchardt et al. (2012), Kapsner et al. (1995) and Masson-Delmotte et al. (2015). We indicate the possibility for no change in accumulation rate. We also display the accumulation rate vs. temperature relationships from the $P_{\text {sat }}$ approach and from Masson-Delmotte et al. (2015).

For the NEEM LIG deposition site, we detail below the graphical determination of the temperature of the firn col- umn. The intersection between the $\delta^{15} \mathrm{~N}$ contour and the "accumulation rate vs. temperature" evolution curve or the horizontal lines showing LIG possible accumulation rate levels gives the range of realistic LIG accumulation rate ( $y$ axis) and temperature ( $x$ axis). Let us assume that the LIG accumulation rate at the NEEM deposition site was the same as today at NEEM, despite increasing temperature. In this conservative case, our $\delta^{15} \mathrm{~N}$ data point to a $3.5^{\circ} \mathrm{C}$ warmer firn column. Assuming a $20 \%$ accumulation increase at the NEEM deposition site leads to an estimate of $4.5^{\circ} \mathrm{C}$ surface warming between the NEEM upstream deposition site and the current NEEM firn temperature. From the intersection between the $\delta^{15} \mathrm{~N}$ level measured in the NEEM LIG section and the accumulation rate estimates from the $P_{\text {sat }}$ approach or the maximum accumulation rate deduced from Buchardt et al. (2012) and Kapsner et al. (1995), we obtain a larger estimate of $6-7{ }^{\circ} \mathrm{C}$ warming of the firn column at the NEEM LIG deposition site compared to the current NEEM firn temperature. This corresponds to an accumulation rate of $26-30 \mathrm{~cm}$ water equivalent $\mathrm{yr}^{-1}$, i.e., $32-50 \%$ higher than the presentday accumulation rate at NEEM. The highest LIG warming compatible with the $\delta^{15} \mathrm{~N}$ data (almost $-20^{\circ} \mathrm{C}$, i.e., about $9{ }^{\circ} \mathrm{C}$ above present-day NEEM values at the upstream NEEM deposition site) corresponds to an accumulation rate of $46 \mathrm{~cm}$ water equivalent $\mathrm{yr}^{-1}$, i.e., $130 \%$ higher than the presentday accumulation rate at NEEM, using the slope for the relationship between accumulation rate vs. temperature given in Masson-Delmotte et al. (2015). For the ${ }^{10} \mathrm{Be}$ approach, which represents an upper limit of the possible accumulation increase, we find a LIG temperature $7-8^{\circ} \mathrm{C}$ warmer than at the current drilling site. When corrected for the change in deposition site, this translates to a $6-11^{\circ} \mathrm{C}$ higher temperature at the NEEM deposition site for LIG compared to the preindustrial temperature level.

At NGRIP, the same graphical approach leads to an estimated temperature of -28.5 to $-24{ }^{\circ} \mathrm{C}$ at the end of the LIG (120 ka on the AICC2012 timescale) compared to $-31.5^{\circ} \mathrm{C}$ for the preindustrial period, i.e., a difference of $+5.2 \pm 2.3^{\circ} \mathrm{C}$ between $120 \mathrm{ka}$ and the preindustrial period. Even if NGRIP is not on a dome, the upstream effect is quite small: the NGRIP LIG deposition site is estimated to lie $48 \mathrm{~km}$ upstream in the direction of Summit with small associated altitude gradients between NGRIP and Summit (Buchardt, 2012). Similar to the NEEM temperature reconstruction, the NGRIP LIG temperature uncertainty range arises from the uncertainty in the accumulation rate vs. temperature relationship. The full range of estimates for the accumulation difference at NGRIP from the preindustrial period to the LIG is hence estimated to be $0-100 \%$ of the preindustrial value. This $+5.2 \pm 2.3^{\circ} \mathrm{C}$ warming at $120 \mathrm{ka}$ may be an underestimation of the full warming range encompassed during the LIG because the NGRIP ice core does not extend towards the warmest part of the LIG. At the NEEM deposition site however, the temperature estimated following the graphical method of Fig. 3 from the $\delta^{15} \mathrm{~N}$ value at $120 \mathrm{ka}$ 


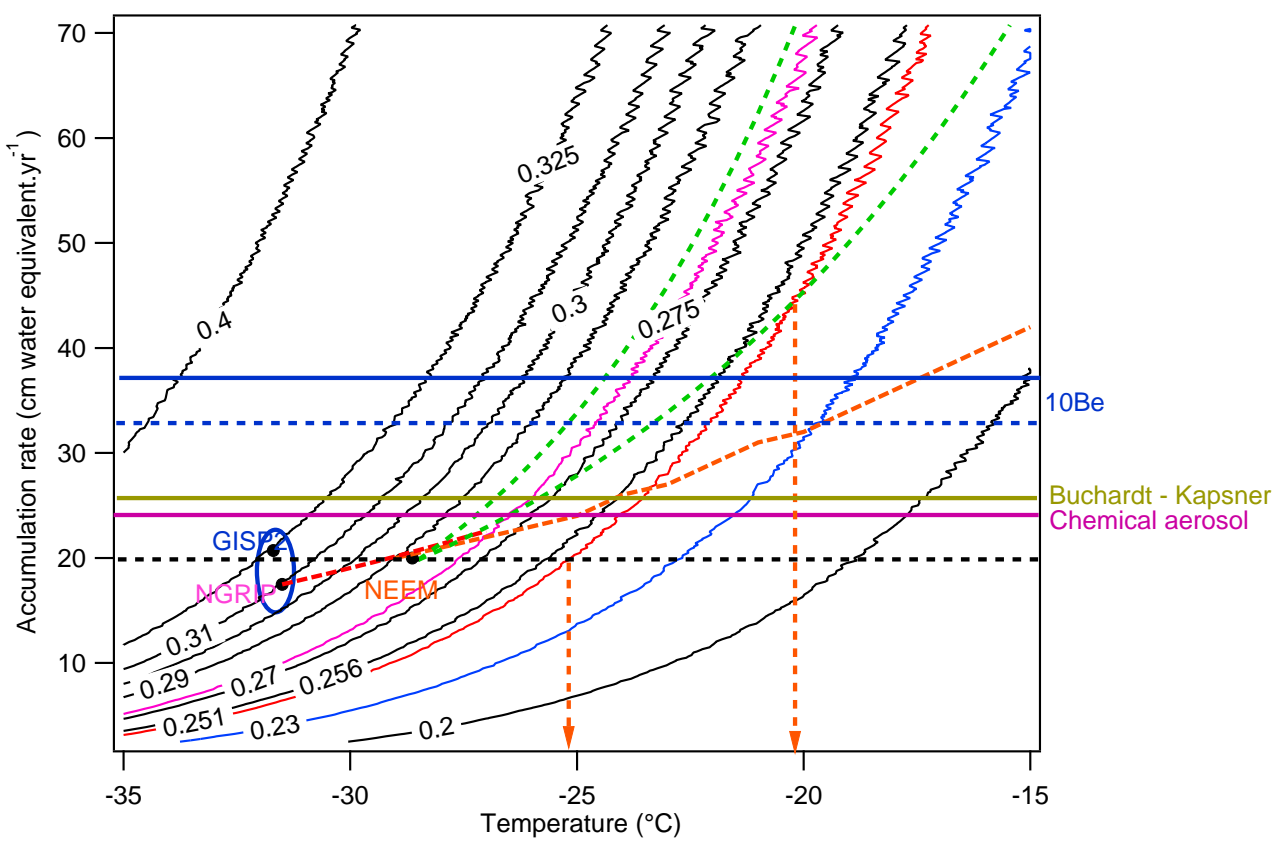

Figure 3. Contour plot showing the evolution of modeled $\delta^{15} \mathrm{~N}$ with respect to accumulation rate estimates for LIG at NEEM. The black circles indicate the accumulation rate vs. temperature for preindustrial conditions for the three Greenland sites discussed here: Summit, NGRIP and NEEM. The dashed horizontal black line indicates the preindustrial level of NEEM accumulation rate; the khaki horizontal solid line stands for the maximum accumulation rate estimate from Buchardt et al. (2012) and Kapsner et al. (1995); the purple horizontal solid line stands for the NEEM deposition site LIG accumulation rate best guess estimate from chemical aerosol species; the dashed and solid blue horizontal lines show the minimum and maximum accumulation rates estimate for the NEEM deposition site at LIG proposed by Sturevik-Storm et al. (2014) on the basis of the ${ }^{10}$ Be concentration; the red dashed curve and the green dashed curves indicate the relationship between accumulation and temperature deduced, respectively, from the $P_{\text {sat }}$ approach and the "Masson-Delmotte approach". The red contour line indicates the NEEM deposition site LIG $\delta^{15} \mathrm{~N}$ level excluding the peak at $2384 \mathrm{~m}$. The two vertical arrows indicate the highest and lowest NEEM LIG temperature as determined by the graphical determination (see text). The thin pink contour line indicates the NGRIP LIG $\delta^{15} \mathrm{~N}$ level and the blue contour line indicates the GRIP/GISP2 LIG $\delta^{15} \mathrm{~N}$ level. The blue circle illustrates the range of possible present-day values for GISP2 $\delta^{15} \mathrm{~N}$.

$\left(0.256 \%\right.$ ) is only $0.5^{\circ} \mathrm{C}$ lower than the estimated LIG optimum temperature and hence very comparable to the estimated LIG optimum temperature. In summary, the NGRIP LIG vs. preindustrial temperature increase $\left(+5.2 \pm 2.3^{\circ} \mathrm{C}\right)$ is thus at the lower end but still compatible within error bars with the NEEM LIG vs. preindustrial temperature increase $\left(+8 \pm 2.5^{\circ} \mathrm{C}\right.$ at $120 \mathrm{ka}$ using the aforementioned $\delta^{15} \mathrm{~N}$ value of $0.256 \%$ o). Several explanations can be given for this discrepancy. First, the dating of the NGRIP and NEEM bottom parts is difficult because of the lack of precise relative and absolute age markers; this limits our confidence when we want to compare $\delta^{15} \mathrm{~N}$ levels of the same age on the two different cores. Second, we do not have any evidence of melt layers at the bottom of the NGRIP core, opposite to NEEM. This suggests that the NEEM deposition site was indeed warmer than NGRIP at LIG but also suggests that firn densification may have been affected by this process at NEEM which would bias our reconstruction. Finally, our temperature reconstruction at NEEM is complicated by the fact that the NEEM LIG deposition site and NEEM drilling site have different surface conditions. In particular, an estimate of the preindustrial accumulation rate is missing at the NEEM deposition site.

At Summit, only very high temperatures can be reconciled with LIG $\delta^{15} \mathrm{~N}$ values 0.7 to $0.9 \%$ lower than today: -20 to $-16^{\circ} \mathrm{C}$ according to graphical determination using Fig. 3 compared to a preindustrial temperature of $-31.7^{\circ} \mathrm{C}$. Still, without a continuous sequence of interglacial ice at Summit, the true origin of the $\delta^{15} \mathrm{~N}$ signal at Summit is doubtful. We cannot yet assess whether this signal is purely gravitational or whether it is dominated by a thermal signal or a firn hiatus effect of $\sim 16 \mathrm{~m}$ as estimated from the barometric Eq. (1).

Finally, note that the present-day values in accumulation, temperature and $\delta^{15} \mathrm{~N}$ at NGRIP and NEEM nicely align with the accumulation-temperature relationship from the $P_{\text {sat }}$ approach (Fig. 3). At Summit, the current accumulation rate is significantly higher than expected from this estimate, indicating that other advective moisture pathways come into play, consistent with analyses of spatial influences of weather regimes in Greenland. Indeed, Ortega et al. (2014) investigated the influence of the main North Atlantic weather 
regimes in Greenland and stressed differences between Summit (affected by NAO+ and NAO- weather regimes) and north/northwest Greenland (more strongly affected by, e.g., the North Atlantic Ridge regime). Accordingly, we do not include the Summit values in our conclusions.

\subsubsection{Limitations of the $\delta^{15} \mathrm{~N}$-based temperature reconstruction at the NEEM sites}

In the following, limits inherent to this $\delta^{15} \mathrm{~N}$ approach are highlighted, which shall motivate further studies to refine the temperature estimate. First, we have applied a firnification model optimized for present-day central Greenland firn to past periods with different, warmer conditions, outside the range of model validation. For instance, the occurrence of substantial summer melt could accelerate firn densification and produce a smaller close-off depth (and therefore smaller $\delta^{15} \mathrm{~N}$ values) than expected from the Goujon model for a given temperature. In principle, the validity of firn models in such a temperature range can be tested if firn studies are performed at Greenland sites which are today warmer than the central deep drilling sites of Summit, NGRIP and NEEM, but no data are yet available. Second, the relative changes in accumulation rates and temperature between the NEEM deposition site and NEEM remain difficult to estimate. Finally, we have identified a negative peak in the NEEM LIG $\delta^{15} \mathrm{~N}$ profile, at $2384 \mathrm{~m}(121 \mathrm{ka})$, with no parallel signal in $\delta^{18} \mathrm{O}_{\text {ice }}$ or in chemical records. This signal challenges our attribution of $\delta^{15} \mathrm{~N}$ variations solely to changes in accumulation rate and/or temperature and suggests the potential influence of surface melt on firn depth, LID and therefore $\delta^{15} \mathrm{~N}$. While the overall stability of the NEEM $\delta^{15} \mathrm{~N}$ record over the LIG supports a gravitational/climatic interpretation, a dominant influence of surface melt explaining a removal of snow cannot be excluded for the Summit ice core sections associated with very low $\delta^{15} \mathrm{~N}(0.23 \%$ ).

\subsection{LIG temperatures in Greenland as estimated by climate models}

The LIG climate has been simulated by a suite of climate models of various complexities. Most of these simulations are included in the model intercomparison studies of Lunt et al. (2013) and Bakker et al. (2013, 2014). The former study compared equilibrium ("snap-shot") simulations, covering time slices within the early LIG (125-130 ka), to temperature proxy data, whereas the latter studies discussed transient simulations covering the entire LIG. The equilibrium simulations are all described in detail in Lunt et al. (2013): they comprise 11 general circulation models (GCMs) and 3 earth system models of intermediate complexity (EMICs). The resolution varies between $\mathrm{T} 21\left(\sim 5.6 \times 5.6^{\circ}\right)$ for the EMICs to $\mathrm{T} 85\left(\sim 1.4^{\circ}\right)$ for the highest-resolution model. All the results are interpolated to grids of $3.75^{\circ}$ (longitude) $\times 2.5^{\circ}$ (latitude) . The transient simulations are described in detail in Bakker et al. (2013, 2014). These are also a combination of GCMs and EMICs, but the highest resolution is only about $3.75^{\circ}$. The main forcing for all the simulations is through orbital parameters and greenhouse gasses. Note that in the majority of the simulations the land-sea configuration, ice sheet extent and height are kept the same as in their respective preindustrial simulations.

The model mean of all equilibrium simulations computes an annual mean temperature increase over Greenland between 0 and $2{ }^{\circ} \mathrm{C}$ with respect to preindustrial control simulations (Fig. 6a of Lunt et al., 2013). At the upstream NEEM deposition site, the same range of annual mean temperature increase is found when analyzing the individual model simulations for the $125 \mathrm{ka}$ time slice $\left(0.2-2.2{ }^{\circ} \mathrm{C}\right.$, Fig. 4). The majority of the transient models simulate a maximum early LIG temperature increase of a similar magnitude to the equilibrium model simulations. This result is not sensitive to the choice of the grid point in the model: when the same analysis is performed for the grid boxes surrounding the NEEM upstream grid box, the maximum of $2^{\circ} \mathrm{C}$ from LIG external forcing is still valid. Two exceptions to this $0-2{ }^{\circ} \mathrm{C}$ warming are (1) the MPI-UW model that computes an annual mean temperature increase as high as $\sim 4^{\circ} \mathrm{C}$ around $126 \mathrm{ka}$ and (2) the transient simulation of CCSM3, which consistently simulates lower annual mean temperatures for the LIG compared to the preindustrial period.

The LIG temperature and precipitation patterns produced by climate models can be applied as a forcing to ice sheet models simulating the LIG evolution of the Greenland ice sheet (e.g., Otto-Bliesner et al., 2006; Robinson et al., 2011; Born and Nisancioglu, 2012; Stone et al., 2013). Several uncertain parameters within these ice sheet models need to be considered (e.g., basal sliding parameter). This, in combination with uncertainties in the schemes translating the largescale climate forcing to the local Greenland mass balance schemes, results in a large ensemble of possible melting scenarios for the Greenland ice sheet for each individual ice sheet model study. Present-day observations and paleo proxy data help to reduce this large spread. In particular, the paleo information of limited surface elevation reduction at the central ice core locations strongly constrains the simulated LIG Greenland ice sheet evolution (Masson-Delmotte et al., 2013).

Here, we investigate the annual mean surface temperature anomaly at the upstream depositional site of NEEM for simulations fulfilling the (paleo) data constraints in the ice sheet modeling studies of Stone et al. (2013). For these simulations, the corresponding modeled annual mean surface temperature anomaly at the upstream NEEM depositional site is around $1-4^{\circ} \mathrm{C}$ above the preindustrial period. The annual mean LIG temperature forcing applied in these two studies is similar (Fig. 4, HadCM3_Bris vs. NorESM_BCCR), whereas the summer temperature anomaly is about $1{ }^{\circ} \mathrm{C}$ larger over central Greenland in Stone et al. (2013). Also, the ice sheet models and the methods for calculating the surface 


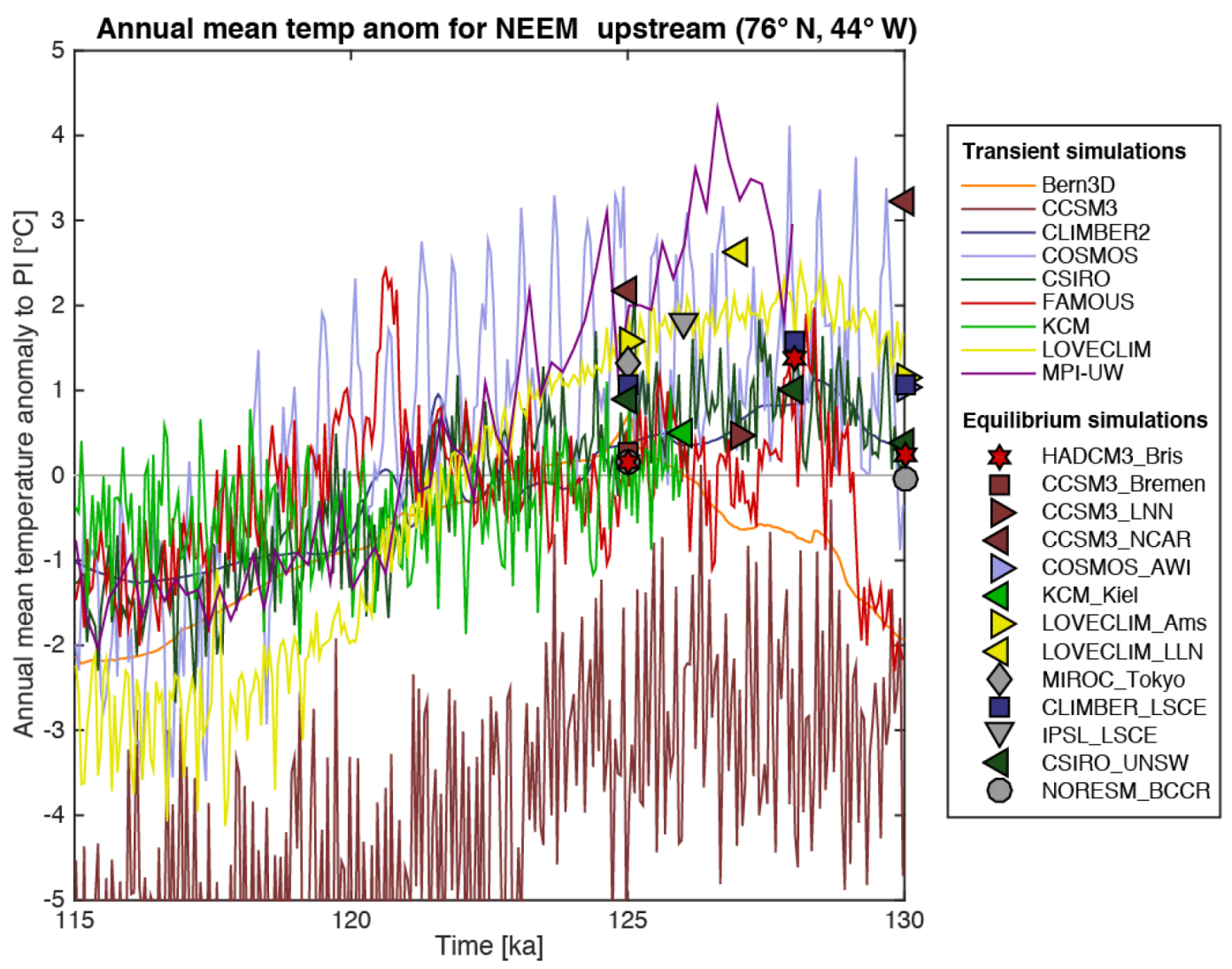

Figure 4. Annual mean temperature anomaly relative to preindustrial control simulations for the upstream NEEM depositional site extracted from transient and equilibrium climate model simulations. Note the similarity for the annual mean temperature increase at 125 and $130 \mathrm{ka}$ as simulated by HadCM3_Bris and NorESM_BCCR. For more information on the climate models and the simulations themselves, we refer to the compilation studies and references therein (Bakker et al., 2013, 2014; Lunt et al., 2013).

mass balance from the climate forcing are different. However, the surface temperature anomaly scenario in these studies is mainly restricted by the limited surface elevation reduction during the LIG implied by NEEM data (NEEM community members, 2013). Assuming this elevation reconstruction to be correct, ice sheet simulations associated with a surface temperature anomaly higher than approximately $4-5^{\circ} \mathrm{C}$ are interpreted to reflect too large an elevation lowering at the ice core locations and are therefore rejected.

In the modeling studies described above, the feedback of changes in surface elevations on the climate is either not included (surface topography is kept fixed) or not well resolved due to coarse model resolution (Stone et al., 2013). However, Merz et al. (2014a) showed that a steeper surface slope can cause an additional $1-3^{\circ} \mathrm{C}$ surface air temperature increase due to an increase in katabatic winds which foster downward flux of sensible heat. In order for this effect to be important for NEEM, the ice sheet geometry needs to change such that its LIG depositional site is closer to the rim of the ice sheet, e.g., with large melting in northeast Greenland.

Confirming the suggestion of Sime et al. (2013), Merz et al. (2016) used the CCSM3 and CCSM4 models to demon- strate that the large spread in Greenland SAT change among the LIG equilibrium simulations (Fig. 4, Lunt et al., 2013) is mostly due to differences in simulated sea ice extent. They showed that surface air temperature and accumulation changes at the NEEM LIG deposition site are particularly sensitive to sea ice retreat in the Nordic Seas.

In summary, studies performed with atmospheric models suggest that a number of processes may combine to produce larger amplitude of warming as simulated in state-of-the-art coupled climate models. They suggest that Greenland LIG surface air temperature change can be amplified in response to regional sea ice retreat and in response to a change in the ice sheet topography. For the NEEM deposition site, LIG annual mean surface temperatures of approximately $5^{\circ} \mathrm{C}$ above preindustrial temperatures can be obtained: $2^{\circ} \mathrm{C}$ being due to LIG external forcing (orbital and greenhouse gases), 0.6 to $2.3{ }^{\circ} \mathrm{C}$ to be attributed to a decrease in sea ice in the Nordic Seas and 1 to $2{ }^{\circ} \mathrm{C}$ associated with a moderately smaller Greenland ice sheet (GrIS). Higher temperatures might be possible in more extreme scenarios; however, then it is unlikely that the ice sheet can maintain surface elevations relatively close to modern values for all central deep ice core lo- 
cations as suggested by the ice core records. The coherency between scenarios of large surface air temperature warming and the plausibility of the Greenland ice sheet response still remains to be fully explored. This includes specific analyses of the seasonal aspects of the surface air temperature change but also scrutinizing the elevation change reconstruction of the Greenland ice sheet during the LIG based on air content measurements (NEEM community members, 2013).

\section{Conclusions and perspectives}

In this study, we have compiled the Greenland ice core data and methods available to quantify LIG temperature change. New estimates of temperature change were provided based on $\delta^{15} \mathrm{~N}$ and firn densification modeling, largely independent of water stable isotope data. They imply that the mean annual firn temperature at the LIG deposition site, upstream of the current NEEM site, experienced $6-11^{\circ} \mathrm{C}$ warming, without correcting for changes in elevation related to ice thickness change. As a comparison, the initial estimate of NEEM community members (2013) based on $\delta^{18} \mathrm{O}$-temperature relationships calibrated against Holocene data led to a LIG surface air temperature at the upstream NEEM deposition site $5.7-9.3^{\circ} \mathrm{C}$ warmer than in the preindustrial period (NEEM community members, 2013).

In addition to the $\delta^{15} \mathrm{~N}$ temperature reconstruction, ice core data provide multiple lines of evidence of significantly warmer conditions, at least during summer, at the upstream NEEM deposition site during the LIG than today at the NEEM site such as in situ $\mathrm{CH}_{4}$ production likely due to summer melt and firn shrinking suggested by the $\delta^{15} \mathrm{~N}$ peak at $2384 \mathrm{~m}$.

However, it shall be noted that our reconstruction is associated with large uncertainties because the Greenland accumulation rate during the LIG is not precisely constrained. In addition, uncertainties are enhanced at NEEM because of the distance between the locations of the NEEM drilling site and the NEEM deposition site. The NGRIP site was less affected by ice flow and the temperature estimate is $3-7.5^{\circ} \mathrm{C}$ higher at $120 \mathrm{ka}$ than for the preindustrial period. This temperature estimate corresponds to the lower limit of the LIG temperature estimate for the NEEM deposition site and suggests that the upper limit of this temperature reconstruction at the NEEM deposition site is not realistic because of too high an accumulation rate.

The evidence of summer melt in the LIG section of the NEEM core is an additional limitation of our approach for the NEEM temperature reconstruction that shall be taken into account. Melting and refreezing, which accelerates firnification processes, is not included in our firnification model, which, strictly speaking, is only valid for the dry snow zone. Still, the occurrence of extensive summer melt implies that mean summer temperatures at the site of deposition frequently reached the melting point, which is about $5^{\circ} \mathrm{C}$ higher than preindus- trial mean summer temperatures at NEEM. Accordingly, the LIG surface conditions were very similar to the extraordinary 2012 heat wave over Greenland, which led to substantial surface melting at the NEEM site.

Large warming at the NEEM deposition site is difficult to reconcile with climate simulations in response to orbital forcing and greenhouse gas concentration forcing only when keeping the LIG ice sheet thickness similar to today's value. State-of-the-art intermediate complexity or fully coupled climate models mostly produce an annual mean temperature increase of less than $2{ }^{\circ} \mathrm{C}$ above preindustrial values during the LIG in NW Greenland. However, sea ice cover retreat in the Nordic Seas and changes in Greenland ice sheet topography may significantly enhance surface warming (Merz et al., 2014a, 2016) and therefore reduce the gap with our estimate. Vice versa, relaxing the ice sheet thickness constraint derived from the ice core measurements (NEEM community members, 2013) allows for much stronger surface warming at the LIG deposition sites.

Further work is required to overcome the unavoidable limitations of firn in our temperature estimate. New firn monitoring studies in Greenland areas affected by summer melt and in today's ablation zone are crucially needed to improve firn modeling and interpretation of the $\delta^{15} \mathrm{~N}$ signal, especially for the sharp anomaly suggested to reflect $16 \mathrm{~m}$ firn shrinking. Similarly, monitoring of water stable isotopes in Arctic water vapor is also critical to better understand and model the relationships between atmospheric circulation, moisture transport pathways, snow-vapor isotopic exchanges and the isotopic composition above the Greenland ice sheet.

Acknowledgements. NEEM is directed and organized by the Centre of Ice and Climate at the Niels Bohr Institute and US NSF, Office of Polar Programs. It is supported by funding agencies and institutions in Belgium (FNRS-CFB and FWO), Canada (NRCan/GSC), China (CAS), Denmark (FIST), France (IPEV, CNRS/INSU, CEA and ANR), Germany (AWI), Iceland (RannIs), Japan (NIPR), South Korea (KOPRI), the Netherlands (NWO/ALW), Sweden (VR), Switzerland, the United Kingdom (NERC) and the USA (USNSF, Office of Polar Programs) and the EU Seventh Framework programs. The Division for Climate and Environmental Physics, Physics Institute, University of Bern, acknowledges continuing support by the Swiss National Science Foundation as well as access to the infrastructure at the Swiss National Supercomputing Centre. The HadCM3 climate model simulations were carried out using the computational facilities of the Advanced Computing Research Centre, University of Bristol - http://www.bris.ac.uk/acrc/. This project benefitted from support from Past4Future "Climate change - Learning from the past climate", a collaborative project under the 7th Framework Programme of the European Commission (grant agreement no. 243908). Petra M. Langebroek is funded by the Research Council of Norway through the IceBed project (221598). This work was supported by European Research Council Advanced Grant no. 246815 WATERundertheICE. The research leading to these results has received funding from the European Research Council under the 
European Union's Seventh Framework Programme (FP7/20072013)/ERC grant agreement no. 306045 (COMBINISO) and from Agence Nationale de la Recherche (ANR-07-VULN-0009 and ANR-10-CEPL-0008). We thank the two reviewers for their helpful comments that permitted us to significantly improve the first version of this manuscript.

Edited by: A. Dutton

Reviewed by: E. W. Wolff and one anonymous referee

\section{References}

Arthern, R. J., Vaughan, D. G., Rankin, A. M., Mulvaney, R., and Thomas, E. R.: In situ measurements of Antarctic snow compaction compared with predictions of models, J. Geophys. Res.Earth Surf., 115, F03044, doi:10.1029/2009JF001543, 2010.

Bakker, P., Masson-Delmotte, V., Martrat, B., Charbit, S., Renssen, H., Gröger, M., Krebs-Kanzow, U., Lohmann, G., Lunt, D. J., Pfeiffer, M., Phipps, S. J., Prange, M., Ritz, S. P., Stenni, B., Stone, E. J., and Varma, V.: Temperature trends during the Present and Last Interglacial periods - a multi-model-data comparison, Quaternary Sci. Rev., 99, 224-243, 2014.

Bakker, P., Stone, E. J., Charbit, S., Gröger, M., Krebs-Kanzow, U., Ritz, S. P., Varma, V., Khon, V., Lunt, D. J., Mikolajewicz, U., Prange, M., Renssen, H., Schneider, B., and Schulz, M.: Last interglacial temperature evolution - a model inter-comparison, Clim. Past, 9, 605-619, doi:10.5194/cp-9-605-2013, 2013.

Bazin, L., Landais, A., Lemieux-Dudon, B., Toyé Mahamadou Kele, H., Veres, D., Parrenin, F., Martinerie, P., Ritz, C., Capron, E., Lipenkov, V., Loutre, M.-F., Raynaud, D., Vinther, B., Svensson, A., Rasmussen, S. O., Severi, M., Blunier, T., Leuenberger, M., Fischer, H., Masson-Delmotte, V., Chappellaz, J., and Wolff, E.: An optimized multi-proxy, multi-site Antarctic ice and gas orbital chronology (AICC2012): 120-800 ka, Clim. Past, 9, 17151731, doi:10.5194/cp-9-1715-2013, 2013.

Bender, M., Floch, G., Chappellaz, J., Suwa, M., Barnola, J.M., Blunier, T., Dreyfus, G., Jouzel, J., and Parrenin, F.: Gas age-ice age differences and the chronology of the Vostok ice core, 0-100 ka, J. Geophys. Res., 111, D21115, doi:10.1029/2005JD006488, 2006.

Benson, C. S.: Stratigraphic studies in the snow and firn of the Greenland ice sheet, SIPRE Res. Rep., 70, 76-83, 1962.

Born, A. and Nisancioglu, K. H.: Melting of Northern Greenland during the last interglaciation, The Cryosphere, 6, 1239-1250, doi:10.5194/tc-6-1239-2012, 2012.

Box, J. E., Yang, L., Bromwich, D. H., and Bai, L.-S.: Greenland Ice Sheet Surface Air Temperature Variability: 1840-2007, J. Clim., 22, 4029-4049, 2009

Buchardt, S. L., Clausen, H. B., Vinther, B. M., and Dahl-Jensen, D.: Investigating the past and recent $\delta^{18} \mathrm{O}$-accumulation relationship seen in greenland ice cores, Clim. Past, 8, 2053-2059, 10.5194/cp-8-2053-2012, 2012.

Buizert, C., Martinerie, P., Petrenko, V. V., Severinghaus, J. P., Trudinger, C. M., Witrant, E., Rosen, J. L., Orsi, A. J., Rubino, M., Etheridge, D. M., Steele, L. P., Hogan, C., Laube, J. C., Sturges, W. T., Levchenko, V. A., Smith, A. M., Levin, I., Conway, T. J., Dlugokencky, E. J., Lang, P. M., Kawamura, K., Jenk, T. M., White, J. W. C., Sowers, T., Schwander, J., and Blunier, T.:
Gas transport in firn: multiple-tracer characterisation and model intercomparison for NEEM, Northern Greenland, Atmos. Chem. Phys., 12, 4259-4277, doi:10.5194/acp-12-4259-2012, 2012.

Capron, E., Landais, A., Lemieux-Dudon, B., Schilt, A., MassonDelmotte, V., Buiron, D., Chappellaz, J., Dahl-Jensen, D., Johnsen, S., Leuenberger, M., Loulergue, L., and Oerter, H.: Synchronising EDML and NorthGRIP ice cores using $\delta^{18} \mathrm{O}$ of atmospheric oxygen and $\mathrm{CH}_{4}$ measurements over MIS5 (80-123 ka), Quaternary Sci. Rev., 29, 235-246, 2010.

Capron, E., Landais, A., Chappellaz, J., Buiron, D., Fischer, H., Johnsen, S. J., Jouzel, J., Leuenberger, M., Masson-Delmotte, V., and Stocker, T. F.: A global picture of the first abrupt climatic event occurring during the last glacial inception, Geophys. Res. Lett., 39, L15703, doi:10.1029/2012GL052656, 2012.

Capron, E., Govin, A., Stone, E. J., Masson-Delmotte, V., Mulitza, S., Otto-Bliesner, B., Rasmussen, T. L., Sime, L. C., Waelbroeck, C., and Wolff, E. W.: Temporal and spatial structure of multimillennial temperature changes at high latitudes during the Last Interglacial, Quaternary Sci. Rev., 103, 116-133, 2014.

Dällenbach, A., Blunier, T., Flückiger, J., Stauffer, B., Chappellaz, J., and Raynaud, D.: Changes in the atmospheric $\mathrm{CH}_{4}$ gradient between Greenland and Antarctica during the Last Glacial and the transition to the Holocene, Geophys. Res. Lett., 27, 10051008, 2000.

Dansgaard, W.: Stable isotopes in precipitation, Tellus, 16, 436468, 1964

Dee, D. P., Uppala, S. M., Simmons, A. J., Berrisford, P., Poli, P., Kobayashi, S., Andrae, U., Balmaseda, M. A., Balsamo, G., Bauer, P., Bechtold, P., Beljaars, A. C. M., van de Berg, L., Bidlot, J., Bormann, N., Delsol, C., Dragani, R., Fuentes, M., Geer, A. J., Haimberger, L., Healy, S. B., Hersbach, H., Hólm, E. V., Isaksen, L., Kållberg, P., Köhler, M., Matricardi, M., McNally, A. P., Monge-Sanz, B. M., Morcrette, J.-J., Park, B.-K., Peubey, C., de Rosnay, P., Tavolato, C., Thépaut, J.-N., and Vitart, F.: The ERA-Interim reanalysis: configuration and performance of the data assimilation system, Q. J. R. Meteorol. Soc., 137, 656, 553-597, 2011.

Dutton, A., Carlson, A. E., Long, A. J., Milne, G. A., Clark, P. U., DeConto, R., Horton, B. P., Rahmstorf, S., and Raymo, M. E.: Sea-level rise due to polar ice-sheet mass loss during past warm periods, Science, 349, aaa4019, doi:10.1126/science.aaa4019, 2015.

Goujon, C., Barnola, J.-M., and Ritz, C.: Modeling the densification of polar firn including heat diffusion: Application to close-off characteristics and gas isotopic fractionation for Antarctica and Greenland sites, J. Geophys. Res., 108, 4800, doi:10.1029/2003JD003758, 2003.

Grootes, P. M., Stuiver, M., White, J. W. C., Johnsen, S. J., and Jouzel, J.: Comparison of the oxygen isotope records from the GISP2 and GRIP Greenland ice cores, Nature, 366, 552-554, 1993

Guillevic, M., Bazin, L., Landais, A., Kindler, P., Orsi, A., MassonDelmotte, V., Blunier, T., Buchardt, S. L., Capron, E., Leuenberger, M., Martinerie, P., Prié, F., and Vinther, B. M.: Spatial gradients of temperature, accumulation and $\delta^{18} \mathrm{O}$-ice in Greenland over a series of Dansgaard-Oeschger events, Clim. Past, 9, 1029-1051, doi:10.5194/cp-9-1029-2013, 2013.

Hawley, R., Courville, Z. R., Kehrk, L. M., Lutz, E. R., Osterberg, E. C., Overly, T. B., and Wong, G. J.: Recent accumula- 
tion variability in northwest Greenland from ground-penetrating radar and shallow cores along the Greenland Inland Traverse, J. Glaciol., 60, 375-382, doi:10.3189/2014JoG13J141, 2014.

Helsen, M. M., van de Berg, W. J., van de Wal, R. S. W., van den Broeke, M. R., and Oerlemans, J.: Coupled regional climateice-sheet simulation shows limited greenland ice loss during the Eemian, Clim. Past, 9, 1773-1788, 10.5194/cp-9-1773-2013, 2013.

Herron, M. M. and Langway, C. C.: Firn densification: an empirical model, J. Glaciol., 25, 373-385, 1980.

Johnsen, S. J., Clausen, H. B., Dansgaard, W., Gundestrup, N. S., Hammer, C. U., Andersen, U., Andersen, K. K., Dahl-Jensen, D., Steffensen, J. P., Sveinbjörnsdottir, A. E., White, J., Jouzel, J., and Fisher, D.: The $\delta^{18} \mathrm{O}$ record along the Greenland Ice Core Project deep ice core and the problem of possible Eemian climatic instability, J. Geophys. Res., 102, 26397-26410, 1997.

Jouzel, J.: Calibrating the isotopic paleothermometer, Science, 286, 910-911, 1999.

Jouzel, J., Masson-Delmotte, V., Cattani, O., Dreyfus, G., Falourd, S., Hoffmann, G., Minster, B., Nouet, J., Barnola, J.-M., Fisher, H., Gallet, J.-C., Johnsen, S., Leuenberger, M., Loulergue, L., Luethi, D., Oerter, H., Parrenin, F., Raisbeck, G., Raynaud, D., Schilt, A., Schwander, J., Selmo, J., Souchez, R., Spahni, R., Stauffer, B., Steffensen, J.-P., Stenni, B., Stocker, T. F., Tison, J.L., Werner, M., and Wolff, E. W.: Orbital and millennial Antarctic climate variability over the past 800,000 years, Science, 317 , 793-796, 2007.

Kapsner, W. R., Alley, R. B., Shuman, A., Anandakrishnan, S., and Grootes, P. M.: Dominant influence of atmospheric circulation on snow accumulation in Greenland over the past 18,000 years, Nature, 373, 52-54, 1995.

Keegan, K., Albert, M. R., and Baker, I.: The impact of ice layers on gas transport through firn at the North Greenland Eemian Ice Drilling (NEEM) site, Greenland, The Cryosphere, 8, 18011806, doi:10.5194/tc-8-1801-2014, 2014.

Kindler, P., Guillevic, M., Baumgartner, M., Schwander, J., Landais, A., and Leuenberger, M.: Temperature reconstruction from 10 to 120 kyr b2k from the NGRIP ice core, Clim. Past, 10, 887-902, doi:10.5194/cp-10-887-2014, 2014.

Kobashi, T., Severinghaus, J. P., and Kawamura, K.: Argon and nitrogen isotopes of trapped air in the GISP2 ice core during the Holocene epoch (0-11,500 B.P.): Methodology and implications for gas loss processes, Geochim. Cosmochim. Acta, 72, 46754686, 2008.

Krinner, G., Genthon, C., and Jouzel, J.: GCM analysis of local influences on ice core d signals, Geophys. Res. Lett., 24, 28252828, 1997.

Landais, A., Chappellaz, J., Delmotte, M., Jouzel, J., Blunier, T., Bourg, C., Caillon, N., Cherrier, S., Malaize, B., MassonDelmotte, V., Raynaud, D., Schwander, J., and Steffensen, J.: A tentative reconstruction of the last interglacial and glacial inception in greenland based on new gas measurements in the greenland ice core project (grip) ice core, J. Geophys. Res.-Atmos., 108, D184563, doi:10.1029/2002jd003147, 2003.

Landais, A., Steffensen, J. P., Caillon, N., Jouzel, J., MassonDelmotte, V., and Schwander, J.: Evidence for stratigraphic distortion in the Greenland Ice Core Project (GRIP) ice core during Event 5e1 (120 kyr BP) from gas isotopes, J. Geophys. Res., 109, D06214, doi:10.1029/2003JD004193, 2004.
Landais, A., Dreyfus, G., Capron, E., Jouzel, J., Masson-Delmotte, V., Roche, D. M., Prié, F., Caillon, N., Chappellaz, J., Leuenberger, M., Lourantou, A., Parrenin, F., Raynaud, D., and Teste, G.: Two-phase change in $\mathrm{CO}_{2}$, Antarctic temperature and global climate during Termination II, Nat. Geosci., 6, 1062-1065, 2013.

Li, J. and Zwally, H. J.: Modeling the density variation in the shallow firn layer, Ann. Glaciol., 38, 309-313, 2004.

Ligtenberg, S. R. M., Medley, B., Van den Broeke, M. R., and Munneke, P. K.: Antarctic firn compaction rates from repeattrack airborne radar data: II. Firn model evaluation, Ann. Glaciol., 56, 167-174, 2015.

Lorius, C., Ritz, C., Jouzel, J., Merlivat, L., and Barkov, N. I.: A 150000 -year climatic record from Antarctic ice, Nature, 316, 591-596, 1985.

Lunt, D. J., Abe-Ouchi, A., Bakker, P., Berger, A., Braconnot, P., Charbit, S., Fischer, N., Herold, N., Jungclaus, J. H., Khon, V. C., Krebs-Kanzow, U., Langebroek, P. M., Lohmann, G., Nisancioglu, K. H., Otto-Bliesner, B. L., Park, W., Pfeiffer, M., Phipps, S. J., Prange, M., Rachmayani, R., Renssen, H., Rosenbloom, N., Schneider, B., Stone, E. J., Takahashi, K., Wei, W., Yin, Q., and Zhang, Z. S.: A multi-model assessment of last interglacial temperatures, Clim. Past, 9, 699-717, doi:10.5194/cp-9-699-2013, 2013.

Masson-Delmotte, V., Landais, A., Stievenard, M., Hoffmann, G., Cattani, O., Falourd, S., Johnsen, S. J., Jouzel, J., DahlJensen, D., Sveinsbjornsdottir, A., White, J. C. W., Popp, T., and Fischer, H.: Holocene climatic changes in Greenland: Different deuterium excess signals at Greenland Ice Core Project (GRIP) and NorthGRIP, J. Geophys. Res., 110, D14102, doi:10.1029/2004JD005575, 2005.

Masson-Delmotte, V., Braconnot, P., Hoffmann, G., Jouzel, J., Kageyama, M., Landais, A., Lejeune, Q., Risi, C., Sime, L., Sjolte, J., Swingedouw, D., and Vinther, B.: Sensitivity of interglacial greenland temperature and delta o-18: Ice core data, orbital and increased $\mathrm{CO}_{2}$ climate simulations, Clim. Past, 7, 1041-1059, doi:10.5194/cp-7-1041-2011, 2011.

Masson-Delmotte, V., Schulz, M., Abe-Ouchi, A., Beer, J., Ganopolski, A., González Rouco, J. F., Jansen, E., Lambeck, K., Luterbacher, J., Naish, T., Osborn, T., Otto-Bliesner, B., Quinn, T., Ramesh, R., Rojas, M., Shao, X., and Timmermann, A.: Information from Paleoclimate Archives, in: Stocker, T. F., Qin, D., Plattner, G.-K., Tignor, M., Allen, S. K., Boschung, J., Nauels, A., Xia, Y., Bex, V., and Midgley, P. M., Climate Change 2013: The Physical Science Basis. Contribution of Working Group I to the Fifth Assessment Report of the Intergovernmental Panel on Climate Change. Cambridge University Press, Cambridge, United Kingdom and New York, NY, USA, 383-464, 2013.

Masson-Delmotte, V., Steen-Larsen, H. C., Ortega, P., Swingedouw, D., Popp, T., Vinther, B. M., Oerter, H., Sveinbjornsdottir, A. E., Gudlaugsdottir, H., Box, J. E., Falourd, S., Fettweis, X., Gallée, H., Garnier, E., Gkinis, V., Jouzel, J., Landais, A., Minster, B., Paradis, N., Orsi, A., Risi, C., Werner, M., and White, J. W. C.: Recent changes in north-west Greenland climate documented by NEEM shallow ice core data and simulations, and implications for past-temperature reconstructions, The Cryosphere, 9, 14811504, doi:10.5194/tc-9-1481-2015, 2015.

Merz, N., Born, A., Raible, C. C., Fischer, H., and Stocker, T. F.: Dependence of Eemian Greenland temperature reconstruc- 
tions on the ice sheet topography, Clim. Past, 10, 1221-1238, doi:10.5194/cp-10-1221-2014, 2014a.

Merz, N., Gfeller, G., Born, A., Raible, C. C., Stocker, T. F., and Fischer, H.: Influence of ice sheet topography on Greenland precipitation during the Eemian interglacial, J. Geophys. Res., 119, 10749-10768, 2014b.

Merz, N., Born, A., Raible, C. C., and Stocker, T. F.: Warm Greenland during the last interglacial: the role of regional changes in sea ice cover, Clim. Past Discuss., doi:10.5194/cp-2016-12, in review, 2016.

Munk, J., Jezek, K. C., Forster, R. R., and Gogieni, S. P.: An accumulation map for the Greenland dry-snow facies derived from spaceborn radar, J. Geophys. Res.-Atmos., 108, 4297, doi:10.1029/2002JD002481, 2003.

NEEM community members: Eemian interglacial reconstructed from a greenland folded ice core, Nature, 493, 489-494, 2013.

NorthGRIP community members: High resolution climate record of the northern hemisphere reaching into last interglacial period, Nature, 431, 147-151, 2004.

Orsi, A. J., Kawamura, K., Fegyveresi, J. M., Headly, M. A., Alley, R. B., and Severinghaus, J. P.: Differentiating bubble-free layers from melt layers in ice cores using noble gases, J. Glaciol., 61, 585-594, 2015

Ortega, P., Swingedouw, D., Masson-Delmotte, V., Risi, C., Vinther, B., Yiou, P., Vautard, R., and Yoshimura, K.: Characterizing atmospheric circulation signals in Greenland ice cores: insights from a weather regime approach, Clim. Dynam., 43, 2585-2605, 2014

Otto-Bliesner, B. L., Marshall, S. J., Overpeck, J. T., Miller, G. H., $\mathrm{Hu}, \mathrm{A}$., and CAPE Last Interglacial Project members: Simulating Arctic Climate Warmth and Icefield Retreat in the Last Interglaciation, Science, 311, 1751-1753, 2006.

Otto-Bliesner, B. L., Park, W., Pfeiffer, M., Phipps, S. J., Prange, M., Rachmayani, R., Renssen, H., Rosenbloom, N., Schneider, B., Stone, E. J., Takahashi, E., Wei, W., Yin, Q., and Zang, Z. S.: A multi-model assessment of last interglacial temperatures, Clim. Past, 9, 699-717, doi:10.5194/cp-9-699-2013, 2013a.

Otto-Bliesner, B. L., Rosenbloom, N., Stone, E. J., McKay, N. P., Lunt, D. J., Brady, E. C., and Overpeck, J. T.: How warm was the last interglacial? New model-data comparisons, P. T. Roy. Soc. A, 371, 20130097, doi:10.1098/rsta.2013.0097, 2013b.

Petit, J. R., Jouzel, J., Raynaud, D., Barkov, N. I., Barnola, J.-M., Basile, I., Bender, M., Chappellaz, J., Davis, M., Delaygue, G., Delmotte, M., Kotlyakov, V. M., Legrand, M., Lipenkov, V. Y., Lorius, C., Pepin, L., Ritz, C., Saltzman, E., and Stievenard, M.: Climate and atmospheric history of the past 420,000 years from the Vostok ice core, Antarctica, Nature, 399, 429-436, 1999.

Pfahl, S. and Sodemann, H.: What controls deuterium excess in global precipitation?, Clim. Past, 10, 771-781, doi:10.5194/cp10-771-2014, 2014

Ritz, C.: Un modèle thermo-mécanique d'évolution pour le bassin glaciaire Antarctique Vostok-Glacier Byrd: Sensibilité aux valeurs des paramètres mal connus, Ph.D. thesis, Université Joseph Fourier - Grenoble I, 1992.

Robinson, A., Calov, R., and Ganopolski, A.: Greenland ice sheet model parameters constrained using simulations of the Eemian Interglacial, Clim. Past, 7, 381-396, doi:10.5194/cp-7-381-2011, 2011.
Severinghaus, J. P., Sowers, T., Brook, E. J., Alley, R. B., and Bender, M. L.: Timing of abrupt climate change at the end of the Younger Dryas interval from thermally fractionated gases in polar ice, Nature, 391, 6663, 141-146, 1998.

Sime, L. C., Risi, C., Tindall, J. C., Sjolte, J., Wolff, E. W., MassonDelmotte, V., and Capron, E.: Warm climate isotopic simulations: What do we learn about interglacial signals in greenland ice cores?, Quaternary Sci. Rev., 67, 59-80, 2013.

Steen-Larsen, H. C., Masson-Delmotte, V., Sjolte, J., Johnsen, S. J., Vinther, B. M., Breon, F. M., Clausen, H. B., Dahl-Jensen, D., Falourd, S., Fettweis, X., Gallee, H., Jouzel, J., Kageyama, M., Lerche, H., Minster, B., Picard, G., Punge, H. J., Risi, C., Salas, D., Schwander, J., Steffen, K., Sveinbjornsdottir, A. E., Svensson, A., and White, J.: Understanding the climatic signal in the water stable isotope records from the neem shallow firn/ice cores in northwest Greenland, J. Geophys. Res.-Atmos., 116, D06108, doi:10.1029/2010jd014311, 2011.

Steen-Larsen, H. C., Johnsen, S. J., Masson-Delmotte, V., Stenni, B., Risi, C., Sodemann, H., Balslev-Clausen, D., Blunier, T., Dahl-Jensen, D., Ellehoj, M. D., Falourd, S., Grindsted, A., Gkinis, V., Jouzel, J., Popp, T., Sheldon, S., Simonsen, S. B., Sjolte, J., Steffensen, J. P., Sperlich, P., Sveinbjnorsdottir, A. E., Vinther, B. M., and White, J. W. C.: Continuous monitoring of summer surface water vapor isotopic composition above the greenland ice sheet, Atmos. Chem. Phys., 13, 4815-4828, 10.5194/acp-134815-2013, 2013.

Steen-Larsen, H. C., Masson-Delmotte, V., Hirabayashi, M., Winkler, R., Satow, K., Prié, F., Bayou, N., Brun, E., Cuffey, K. M., Dahl-Jensen, D., Dumont, M., Guillevic, M., Kipfstuhl, J., Landais, A., Popp, T., Risi, C., Steffen, K., Stenni, B., and Sveinbjörnsdottír, A.: What controls the isotopic composition of greenland surface snow?, Clim. Past, 10, 377-392, doi:10.5194/cp-10377-2014, 2014.

Steen-Larsen, H. C., Sveinbjörnsdottir, A. E., Jonsson, T., Ritter, F., Bonne, J.-L., Masson-Delmotte, V., Sodemann, H., Blunier, T., Dahl-Jensen, D., and Vinther, B.: Moisture sources and synoptic to seasonal variability of North Atlantic water vapor isotopic composition, J. Geophys. Res.-Atmos., 120, 5721-6304, doi:10.1002/2015JD023234, 2015.

Stone, E. J., Lunt, D. J., Annan, J. D., and Hargreaves, J. C.: Quantification of the greenland ice sheet contribution to last interglacial sea level rise, Clim. Past, 9, 621-639, doi:10.5194/cp-9621-2013, 2013.

Sturevik-Storm, A. S., Aldahan, A., Possnert, G., Berggren, A. M., Muscheler, R., Dahl-Jensen, D., Vinter, B., and Usoskin, I. G.: ${ }^{10} \mathrm{Be}$ climate fingerprints during the Eemian in the NEEM ice core, Greenland, Sci. Rep., 4, 6408, doi:10.1038/srep06408, 2014.

Suwa, M., Fischer, J. C., Bender, M. L., Landais, A., and Brook, E. J.: Chronology reconstruction for the disturbed bottom section of the gisp2 and the grip ice cores: Implications for termination II in Greenland, J. Geophys. Res., 111, D02101, doi:10.1029/2005JD006032, 2006.

Uppala, S. M., KÅllberg, P. W., Simmons, A. J., Andrae, U., Bechtold, V. D. C., Fiorino, M., Gibson, J. K., Haseler, J., Hernandez, A., Kelly, G. A., Li, X., Onogi, K., Saarinen, S., Sokka, N., Allan, R. P., Andersson, E., Arpe, K., Balmaseda, M. A., Beljaars, A. C. M., Van De Berg, L., Bidlot, J., Bormann, N., Caires, S., Chevallier, F., Dethof, A., Dragosavac, M., Fisher, M., Fuentes, 
M., Hagemann, S., Hólm, E., Hoskins, B. J., Isaksen, L., Janssen, P., Jenne, R., Mcnally, A. P., Mahfouf, J.-F., Morcrette, J.-J., Rayner, N. A., Saunders, R. W., Simon, P., Sterl, A., Trenberth, K., Untch, A., Vasiljevic, D., Viterbo, P., and Woollen, J.: The ERA-40 re-analysis, Q. J. R. Meteorol. Soc., 131, 2961-3012, 2005.

van de Berg, W. J., van den Broeke, M. R., van Meijgaard, E., and Kaspar, F.: Importance of precipitation seasonality for the interpretation of eemian ice core isotope records from greenland, Clim. Past, 9, 1589-1600, doi:10.5194/cp-9-1589-2013, 2013.

Veres, D., Bazin, L., Landais, A., Toyé Mahamadou Kele, H., Lemieux-Dudon, B., Parrenin, F., Martinerie, P., Blayo, E., Blunier, T., Capron, E., Chappellaz, J., Rasmussen, S. O., Severi, M., Svensson, A., Vinther, B., and Wolff, E. W.: The Antarctic ice core chronology (AICC2012): an optimized multi-parameter and multi-site dating approach for the last 120 thousand years, Clim. Past, 9, 1733-1748, doi:10.5194/cp-9-1733-2013, 2013.
Vinther, B. M., Buchardt, S. L., Clausen, H. B., Dahl-Jensen, D., Johnsen, S. J., Fisher, D. A., Koerner, R. M., Raynaud, D., Lipenkov, V., Andersen, K. K., Blunier, T., Rasmussen, S. O., Steffensen, J. P., and Svensson, A. M.: Holocene thinning of the greenland ice sheet, Nature, 461, 385-388, 2009.

Vinther, B. M., Jones, P., Briffa, K., Clausen, H., Andersen, K., Dahl-Jensen, D., and Johnsen, S.: Climatic signals in multiple highly resolved stable isotope records from greenland, Quaternary Sci. Rev., 29, 522-538, 2010. 